\title{
Diagenetic impacts on hydraulic flow unit properties: insight from the Jurassic carbonate Upper Arab Formation in the Persian Gulf
}

\author{
Masoud Sharifi-Yazdi ${ }^{1} \cdot$ Hossain Rahimpour-Bonab ${ }^{1} \cdot$ Maziyar Nazemi $^{1} \cdot$ Vahid Tavakoli $^{1} \cdot$ Sajjad Gharechelou $^{1}$
}

Received: 1 June 2019 / Accepted: 7 April 2020 / Published online: 18 April 2020

(c) The Author(s) 2020

\begin{abstract}
The Upper Arab reservoir in the central Persian Gulf was examined for depositional, diagenetic, sequence stratigraphic and petrophysical features. This succession is composed of eight sedimentary facies that deposited on a carbonate ramp. Three-third-order sequences prograded across the Late Jurassic Arab Platform. This interval was complicated by multiple diagenetic phases including eogenesis and mesogenesis that strongly influenced reservoir properties. Dolomitization, dissolution, cementation and compaction are major diagenetic processes which played an essential role in increasing or decreasing reservoir quality. Four hydraulic flow units (HFU) were determined by flow zone indicator approach for evaluation of the reservoir quality. In addition to depositional features, diagenetic alterations have changed general HFUs characterizations such as porosity, permeability and pore-throat size. Likewise, via Lucia classification, HFUs of the Arab reservoir were grouped based on the integration of geological and petrophysical attributes in detail. Among diagenetic processes, dolomitization and dissolution have positive effects while cementation and stylolitization have a negative effect on HFUs characteristics in the studied reservoir. Put another way, since diagenetic alterations lead to the intensification of heterogeneity in carbonate reservoir, prediction of the relationship between pore type and pore throat size is a problematic issue. Recognition of the hydraulic flow units considered as a practical tool for grouping reservoir rocks and characterizing heterogeneity using porosity and permeability relationship. Finally, specifying of the contribution of various diagenetic imprints in each hydraulic flow unit in a sequence stratigraphic framework results in a conceptual reservoir model that could predict reservoir quality variations across the field.
\end{abstract}

Keywords Hydraulic flow unit · Upper Arab Formation · Diagenesis · Lucia classification · Persian Gulf

\section{Introduction}

Carbonate reservoirs show extreme heterogeneity resulted from various parameters including depositional and postdepositional processes. Categorically, diagenetic modifications of the primary (depositional) characteristics lead to the higher heterogeneity and shaping the final reservoir geometry and properties (Mazzullo 1994; Massonnat and Pernarcic 2002; Ahr 2008; Hollis 2011). Thus, the recognition of diagenetic processes and their distribution is necessary for better understanding of the reservoir quality evolution (Moore 2001; Ahr 2008; Rahimpour-Bonab et al. 2012). Meanwhile, the key point is to identify the critical link between

Hossain Rahimpour-Bonab

rahimpor@ut.ac.ir

1 School of Geology, College of Science, University of Tehran, Tehran, Iran the geological heterogeneity, reservoir quality and performance (Chilingarian et al. 1992; Jodry 1992; Wardlaw 1996; Serag et al. 2010; Aliakbardoust and Rahimpour-Bonab 2013; Hamada et al. 2013). Carbonate rocks are specified by the complexity in pore type and pore size distribution, which results in wide permeability variations for the same porosity, making it difficult to predict their production ability (Rahimpour-Bonab 2007; Nazemi et al. 2018). Commonly, most variations are the results of the diagenetic alterations.

As defined (Porras and Campos 2001; Soto et al. 2001; Perez et al. 2005), a hydraulic flow unit is an interval with specified properties which has noticeable development in the reservoir. These units are controlled by both geological and petrophysical attributes which are able to predict reservoir characterization. Accordingly, diagenetic imprints in the carbonate successions are the essential parameter controling the hydraulic flow units. Therefore, detangling the complex diagenetic history of carbonate reservoirs 
(i.e., paragenetic sequences of the diagenetic events) aids to accomplish comprehensive reservoir modeling.

The Arabian Plate hosts numerous prolific hydrocarbon reservoirs. Accordingly, the well-known carbonateevaporite of Arab succession is an important hydrocarbon reservoir in the Middle East (Bates 1973; Alsharhan and Nairn 1997; Marchionda et al. 2018). Reservoir quality of the Arab Formation has been studied in various parts of the Arabian Plate (e.g., Clark et al. 2004; Nader et al. 2013; Daraei et al. 2014; Beigi et al. 2017; Assadi et al. 2018; Sfidari et al. 2018; Sharifi-Yazdi et al. 2019). While these studies mainly focused on the impact of sedimentological and diagenetic factors on the reservoir quality, few studies emphasized on untying the reservoir heterogeneity by petrophysical rock typing. Generally, it is difficult to identify homogenous units, using the integration of petrophysical rock types (flow zone indicator method or FZI), but considering geological attributes makes it possible. In fact, the FZI method is considered as one of the well-known methods to specify hydraulic flow unit on the basis of petrophysical data (porosity and permeability).The recognition of the depositional features and diagenetic modifications is an indispensable part of the description of heterogeneity in the carbonate reservoir. Diagenesis predominantly induced by warm and arid climate pervasively influenced the carbonate Arab reservoir, and the significance of diagenetic modifications in reservoir characterization of this succession is creation, destruction and preservation of reservoir quality (Morad et al., 2012; Assadi et al., 2018). Since sequence stratigraphy illustrates the temporal and spatial distribution of sedimentological and diagenetic characteristics, it can be a useful manner in the prediction of reservoir characterization. In other words, these characteristics have a direct or indirect relationship with sea-level fluctuations; in turn, by this approach (known as a correlatable approach) all data are correlated within the sequence stratigraphic framework of the field. Thus, the analogous characteristics among various exploration wells in the Upper Arab Formation are correlated. The aims of this study include (1) recognizing the impact of diagenetic evolution on the heterogeneity of the Arab reservoir, (2) establishing a sequence stratigraphic model for distribution of diagenetic processes, (3) determination of hydraulic flow units and their relationship with the geological attributes and sequence stratigraphic framework. These could lead to a better understanding of reservoir property distribution, resulted from the heterogeneity of carbonate reservoirs. Constructing a two-dimensional model provides a predictable scheme of geological aspects (especially diagenesis), which depicts the reservoir characteristics variation (Rahimpour-Bonab et al., 2012; Enayati-Bidgoli et al., 2014; Mehrabi et al., 2015).

\section{Geological setting and stratigraphy}

The studied area is situated in the central Persian Gulf in the northeastern of the Arabian Plate, bounded by Zagros fold belt. This field is located in the eastern part of the South Pars Gas Field (Fig. 1). Orogenic activities, including Amar Collision (636-626 million years ago) and then Najd Rift System (570-530 million years ago) (Al-Husseini 2000), are the major tectonic phases which caused Zagros trending, so that led to the northwest-to-southeast trend. The Najd rift faults resulted in the establishment of the Qatar-Fars Arch and salt diapirism. These two structural elements have influenced the formation of the Persian Gulf fields such as the studied region (Alsharhan and Nairn 1997; Perotti et al. 2011). Formation of the Neotethys passive margin as the basin in the Late Permian promoted the accumulation of thick successions (Sharland et al. 2001; Ziegler 2001). The basin had experienced several tectonic events including uplift and subsidence during a geological time, which play a vital role in the depositional style. Following that, tectonic movements during the Jurassic caused the creation of sub-basins containing Gotnia, Arabian and Rub-Alkhali separated by Rhimthan and Qatar-Fars Arch, respectively. The Arab succession was deposited in the Rub-Alkhalisub basin which was impressed by salt and the Qatar-Fars Arch activities.

During the Late Jurassic (Kimmeridgian to Tithonian), Arab carbonate developed in an epiric sea on the Arabian Platform due to sea-level fluctuations, under warm and arid climate (Alsharhan and Nairn 1997; Handford et al. 2002;

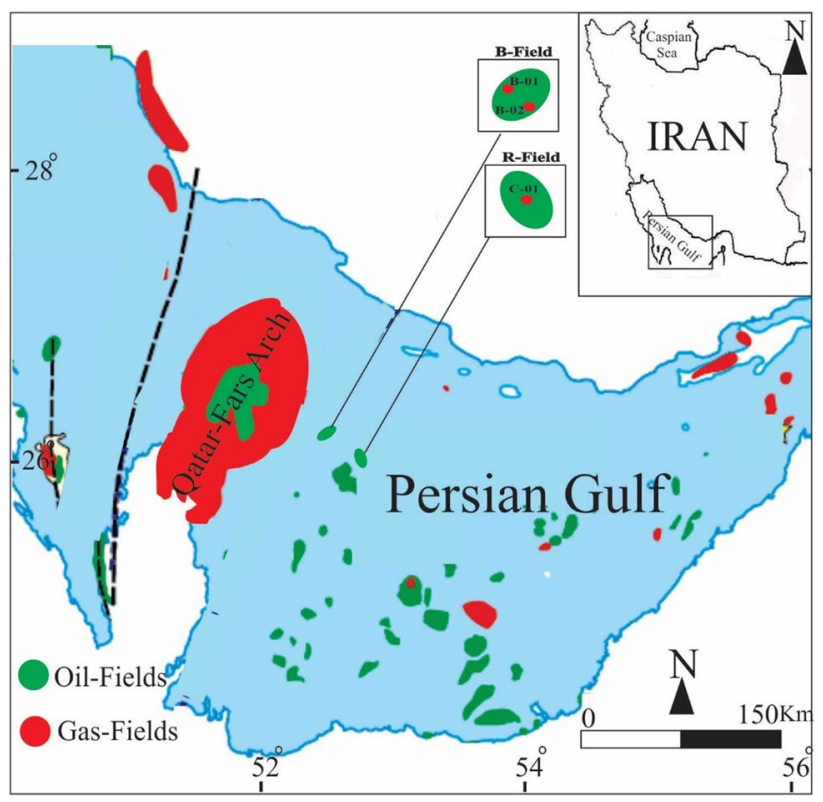

Fig. 1 Location map of studied fields in the central Persian Gulf 
Lindsay et al. 2006). The paleoclimatic changes in the Arabian Plate caused complicated diagenetic processes, in turn. Furthermore, in terms of paleogeographic location, the Arabian Plate was situated in approximately $10-15^{\circ}$ south of the equator that was surrounded by the continental margin and the Neotethys Ocean (Handford et al. 2002).

This formation is overlain by the evaporite Hith Formation. The carbonate-evaporite Arab Formation (equivalent to Upper Surmeh Formation) subdivided into four reservoir units, comprising A, B, C (Upper Arab Formation) and D (Lower Arab Formation) (Fig. 2). Evaporite deposits are responsible for separating different units. In this study, A, $\mathrm{B}$ and $\mathrm{C}$ units were considered which are recognized as the Upper Arab Formation. Dolomite is the main lithology in these units, and then anhydrite is the prevalent lithology.

\section{Materials and methods}

Data for this research were obtained from two cored wells containing B-01 (100 m-thick) and B-02 (100 m-thick) on B-Field and one well including C-01(68 m-thick) on R-Field located in the central Persian Gulf (Offshore Iran). The number of 500 thin sections from core plugs at a spacing that ranges from $30 \mathrm{~cm}$ to $100 \mathrm{~cm}$ were examined in this study. For petrographic analysis of core samples, all thin sections were stained with Alizarin red S based on Dickson (1965) method. For sedimentary facies classification, Dunham (1962) and Embry and Klovan (1971) methods are considered. For depositional modeling, models suggested by Buxton and Pedley (1989) and Flügel (2004) were used. Different data such as facies analysis and petrophysical logs (standard gamma-ray (SGR) and density (RHOB)) were employed for sequence stratigraphic studies. The oxygen and carbon stable isotopes were analyzed for 28 bulk samples from one well (B-01). A total of 500 porosity and permeability data from core plugs were selected for reservoir quality evaluation. Porosity measurement was conducted by the Boyle's law with helium gas, and permeability measurement was conducted by Darcy's law with air. Rock typing was carried out using hydraulic flow unit determination according to the FZI method. The results of 80 mercury injection pressure tests were also considered. High-pressure mercury intrusion tests were carried out to a maximum

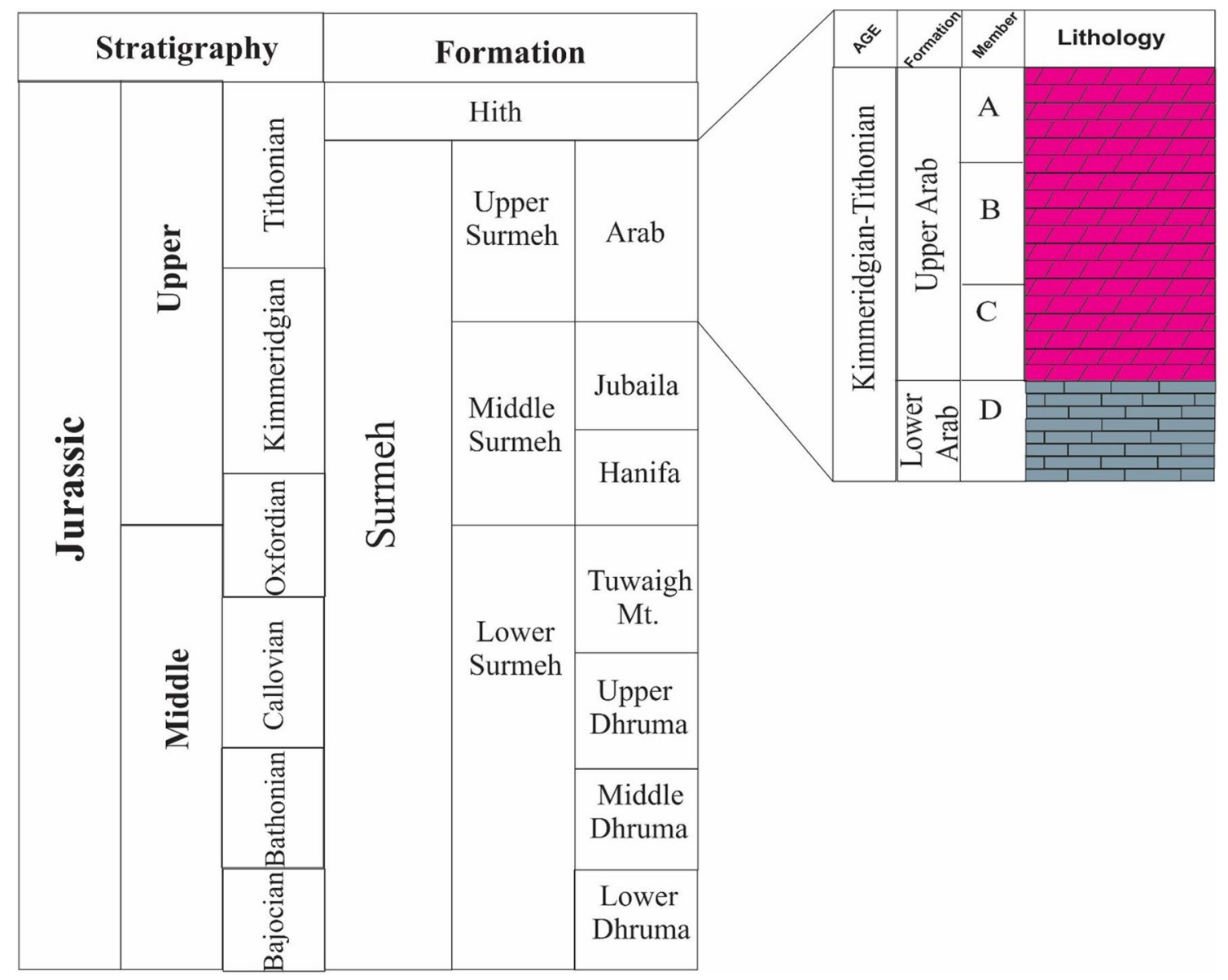

Fig. 2 Stratigraphy column of the Jurassic successions including the Arab Formation 
pressure of 60,000 psi to attain pore-throat size distribution and distribution of pressure against saturation.

\section{Results and discussion}

\section{Depositional framework}

Since the diagenetic events and reservoir quality are primarily controlled by depositional attributes, the sedimentary facies must be investigated in details. Based on petrographic studies, eight sedimentary facies were recognized in the studied intervals (Upper Arab Formation). These facies were grouped in four facies belts, including supratidal, intertidal, lagoon and shoal settings (Fig. 3, Table 1).

\section{F1: Anhydrite}

This facies encompasses anhydrite minerals which have massive, layered and chicken wire forms (Fig. 4a). The crystals of this facies reflect various sizes, ranging from $2 \mathrm{~cm}$ to
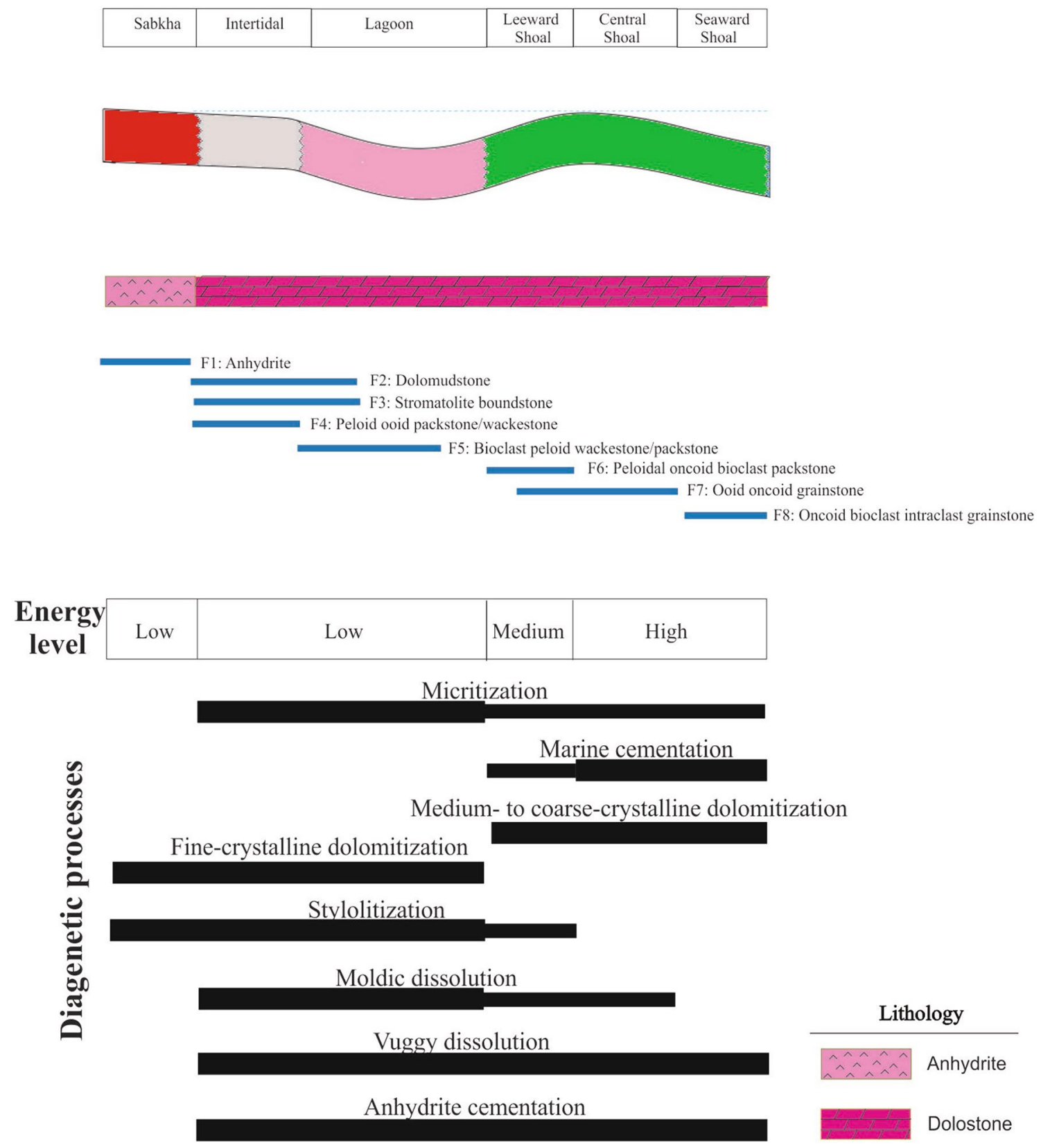

Fig. 3 Depositional model of the Arab Formation reveals the lateral distribution of facies accompanied by diagenetic processes 
Table 1 Main facies and their properties of the Arab Formation in the studied area

\begin{tabular}{|c|c|c|c|c|c|c|c|}
\hline Facies code & Facies name & Components & Size & Sorting & Roundness & Energy level & Facies belt \\
\hline $\mathrm{F} 1$ & Anhydrite & - & - & - & - & Low & Supratidal \\
\hline $\mathrm{F} 2$ & Dolomudstone & - & - & - & - & Low & Intertidal \\
\hline F3 & $\begin{array}{l}\text { Peloidalstromatolite bound- } \\
\text { stone }\end{array}$ & Peloids & Fine & Poor & Poor & Low & Intertidal \\
\hline $\mathrm{F} 4$ & $\begin{array}{l}\text { Peloidal ooid packstone- } \\
\text { wackestone }\end{array}$ & $\begin{array}{l}\text { Peloids, ooids, gastropods, } \\
\text { bivalves }\end{array}$ & Fine tomedium & Good & Good & Medium & Intertidal \\
\hline \multirow[t]{2}{*}{ F5 } & Bioclast peloid & $\begin{array}{l}\text { Gastropods, bivalves, } \\
\text { peloids, oncoids }\end{array}$ & Fine to & Poor & Poor & Low & Lagoon \\
\hline & packstone-wackestone & & medium & & & & \\
\hline F6 & $\begin{array}{l}\text { Peloidal oncoid bioclast } \\
\text { packstone }\end{array}$ & $\begin{array}{l}\text { Peloids, oncoids, gastropods, } \\
\text { bivalves, ooids }\end{array}$ & Medium & Medium & Medium & Medium & Shoal \\
\hline F7 & Ooid oncoid grainstone & $\begin{array}{l}\text { Ooids, gastropods, oncoids, } \\
\text { bivalves, peloids }\end{array}$ & Medium to coarse & Good & Good & Good & Shoal \\
\hline F8 & intraclast grainstone & $\begin{array}{l}\text { Oncoids, gastropods, } \\
\text { bivalves, intraclasts }\end{array}$ & Coarse & Medium & Medium & High & Shoal \\
\hline
\end{tabular}

several meters. This facies occurs in the upper part of each unit of the B-01, B-02 and C-01 wells.

Interpretation The presence of various structures of this facies assigned to supratidal or sabkha setting where crystals are shaped by hypersaline fluids (Fig. 3). Also, this facies does not show reservoir potential.

\section{F2: Dolomudstone}

Dolomudstone facies consists of micrite in addition to fine crystals dolomite (Fig. 4b). The most significant of this facies is the absence of fossil contents. This facies is dominant in the B-01 well and unit B of the C-01 well.

Interpretation The development of micrite illustrates a low-energy environment. Intertidal is a realm to the precipitation of carbonate mud under stagnant condition (Fig. 4). Besides, mud-dominated facies has low reservoir potential.

\section{F3: Peloidal stromatolite boundstone}

This facies chiefly is composed of algal filaments, peloids and fine intraclasts (Fig. 4c). The grains of this facies have poor sorting and roundness. This facies is mainly observed in unit B of three wells (B-01, B-02 and C-01).

Interpretation Algal fragments usually suggest a lowenergy environment situated in intertidal section (Fig. 3). The predominance of micrite has a negative impact on reservoir characterization.

\section{F4: Peloidal ooid packstone-wackestone}

The significant components of this facies include small size $(<1 \mathrm{~mm})$ ooids and peloids that are embedded in a muddy matrix (Fig. 4d). The fragments of this facies are characterized by well-soring and roundness. This facies is dominant in units A and B of the B-01, B-02 and C-01 wells.

Interpretation Based on the kind of textural maturity and the existence of muddy matrix, there is a textural inversion in this facies that can be ascribed to the intertidal zone (Fig. 3). In terms of reservoir quality, micrite occludes pore throats in this facies.

\section{F5: Bioclast peloid packstone-wackestone}

Peloid beside fossil grain-like gastropods and bivalves account for the vast majority grains of this facies (Fig. 4e). These fragments are distributed in carbonate mud. This facies is found in unit A of the B-01 well and throughout the B-02 and C-01 wells.

Interpretation This mud-dominated facies containing fossil contents depicts restricted low-energy lagoon that is restricted by shoal crests (Fig. 3). This facies reveals lowreservoir characterization similar to $\mathrm{F} 2$.

\section{F6: Peloidal oncoid bioclast packstone}

This facies consists of peloids, oncoids and bioclastic particles accompanied by some mud content (Fig. 4f). The most remarkable attribute of the grains this facies that grains are highly sorted and rounded. This facies is seen in units $\mathrm{A}$ and $\mathrm{B}$ of the B-01, B-02 and C-01 wells.

Interpretation The existence of the depositional components with a high level of maturity reflects a leeward shoal setting which is considered a relatively high-energy circumstance (Fig. 3). The paucity of micrite leads to the enhancement of reservoir quality in this facies.

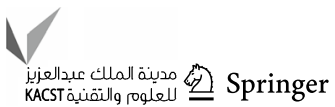


Fig. 4 Thin sections photomicrographs illustrating main facies from the Arab Formation in the central of the Persian Gulf. a F1: anhydrite, b F2: dolomudstone missing bioclast, c F3: stromatolite boundstone, d F4: peloid ooid packstone/ wackestone accompanied with anhydrite nodule, e F5: bioclastic peloid wackestone/ packstone, $\mathbf{f}$ F6: peloidaloncoid bioclastic packstone, g F7: ooid oncoid grainstone, $\mathbf{h}$ F8: oncoid bioclastic intraclast grainstone
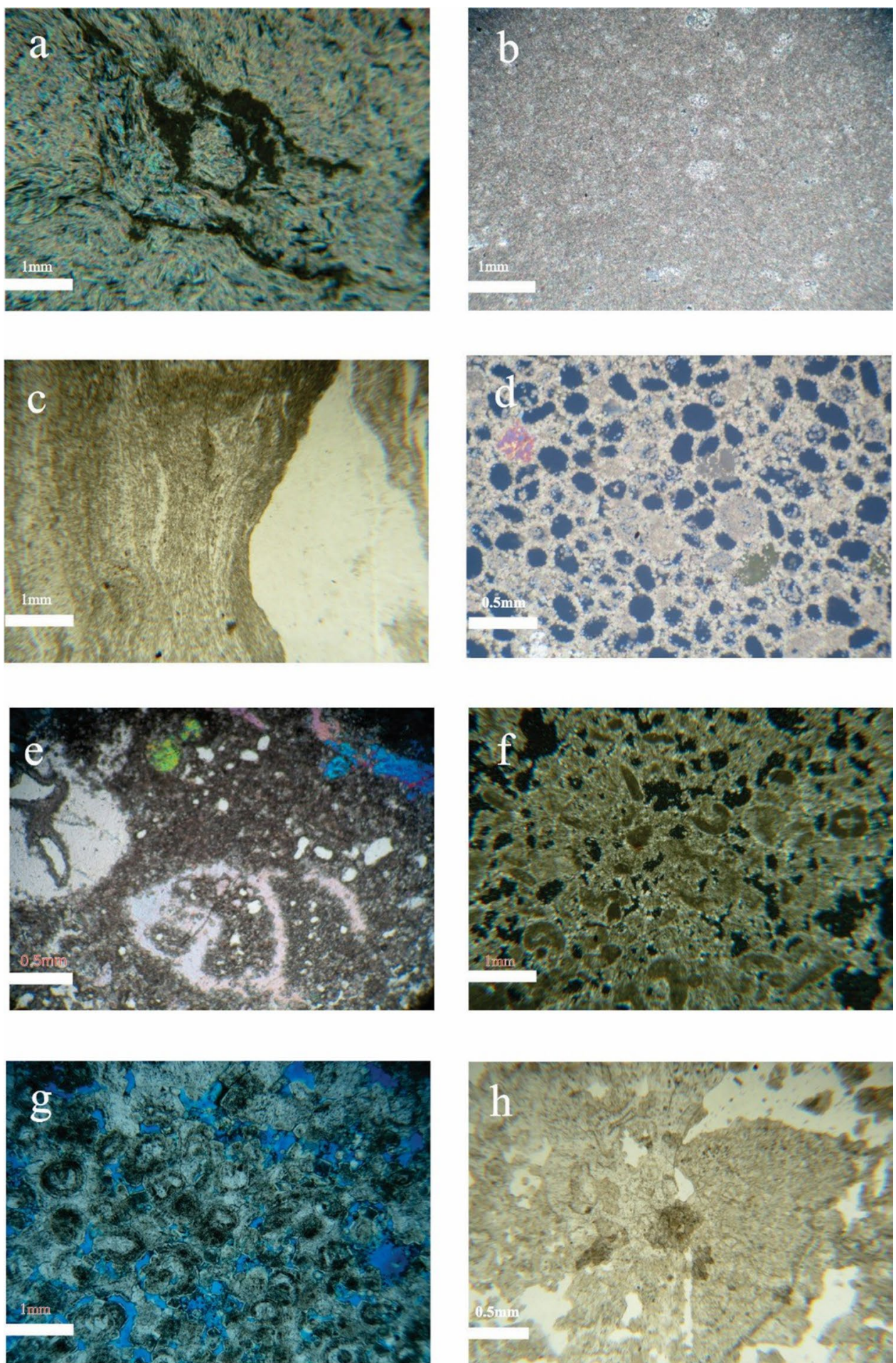

\section{F7: Ooid oncoid grainstone}

Very well-sorted and rounded ooids and oncoids make up this facies (Fig. 4g). This facies is highlighted by the absence of micrite. This facies is prevailing in the whole interval of three wells (B-01, B-02 and C-01).

Interpretation The deposition of the very well-sorted allochems suggesting a high-energy shoal realm (Fig. 3). Regarding the identified characteristics, this facies has high-reservoir potential. 


\section{F8: Oncoid bioclast intraclast grainstone}

This predominantly includes bioclasts, peloids and intraclasts (Fig. 4h). These allochems are highlighted by moderate sorting and roundness with grain-dominated fabric. This facies has a low frequency in all wells (B-01, B-02 and C-01).

Interpretation Respecting the abundant broken grains such as intraclasts and textural maturity, this facies was deposited in a seaward shoal with high-energy situation (Fig. 3). This high-energy facies similar to F7 has high potential of reservoir quality as a result of its textural maturity.

\section{Depositional model}

Recognition of depositional facies aids to reconstruct the sedimentary environment and also exhibit a depositional model. The Arab carbonate ramp (Handford et al. 2002; Lindsay et al. 2006; Morad et al. 2012; Daraei et al. 2014; Sharifi-Yazdi et al. 2019) was developed under hot and arid climate (Alsharhan and Magara 1995; Hollis et al. 2017) on the Arabian Plate. This carbonate-evaporite platform was constructed from multiple sedimentary facies that laterally and vertically developed (Fig. 3).

These facies primarily have low reservoir potential, although diagenetic features such as dissolution led to reservoir improvement. Shoal facies (Fig. 4f, g, h) mainly includes grain-dominated facies which represents a highenergy condition. The highest porosity and permeability were found in the shoal facies (Daraei et al. 2014; Hollis et al. 2017) showing remarkable propagation toward the Northeast (Cantrell 2006). Even though grainstone facies shows better reservoir quality, diagenetic effects caused higher heterogeneity, as well (Assadi et al. 2018).

\section{Depositional sequences}

According to the petrographic studies and petrophysical logs (GR and RHOB), sequences and stratigraphic surfaces (maximum flooding surface and sequence boundary) were recognized. The sequence boundaries were highlighted by evaporite deposits, along with decreasing GR log and increasing RHOB log.

\section{Sequence C}

This depositional sequence (almost $28 \mathrm{~m}$ ) contains TST and HST. The TST with $15 \mathrm{~m}$ thickness includes highenergy shoal facies (F7) possessing retrogradational pattern. The MFS is characterized by seaward shoal facies (F8) and rise in GR logs. HST with $13 \mathrm{~m}$ thickness is chiefly made up of mud-dominated facies (F5 and F6) that indicate progradational geometry. The sequence boundary is recognized by anhydrite layer and an increase in RHOB logs.

\section{Sequence B}

Sequence B is approximately $38 \mathrm{~m}$ and is composed of TST and HST. The TST (13 m-thick) starts with low-energy facies (F2, F3 and F4) and is retrogradationally followed by grainstone facies (F7) in B-01 and B-02 wells. By contrast, this systems tract contains central shoal facies (F7) in the C-01 well. The MFS is highlighted by oncoid bioclastic intraclast grainstone facies and increased GR logs in this sequence. Also, the HST ( $25 \mathrm{~m}$ thick) includes mud-dominated facies (F2-F6) progradationally continues with anhydrite facies (F1) as the sequence boundary that is associated with an increase in RHOB logs.

\section{Sequence $A$}

This depositional sequence (about $26 \mathrm{~m}$ ) has two systems tracts including TST and HST. Mud-dominated facies (F2, F5 and F6) make up the TST (17 m-thick) that converts to grainstone facies (F7) with retrogradational pattern. Oncoild bioclastic intraclast grainstone facies is identified as the MFS which is along with rise in GR logs. The HST $(9 \mathrm{~m}$ thick) contains ooidal oncoid grainstone facies which progradtionally ends up in the Hith Formation that is considered as the sequence boundary with rose RHOB logs.

Interpretation Other studies on the Upper Arab successions (Azer and Peebles 1995, 1998; Daraei et al. 2014; Sharifi-Yazdi et al. 2019) also represented three-third-order sequences. Each sequence comprises a different sedimentary facies (low-energy to high-energy facies) at various positions. Early transgressive system tract (TST) and late high stand tract (HST) contain low-energy facies (intertidal and lagoon facies) while the late TST and early HST composed of high-energy facies (shoal facies). Consequently, energy increases from the peritidal facies (located near the sequence boundary) to the shoal facies, located in maximum flooding surface.

\section{Diagenetic processes}

According to petrographic studies (Fig. 4), the Upper Arab Formation displays several diagenetic processes such as micritization, marine cementation, dolomitization, dissolution, anhydrite cementation and compaction (Fig. 5).

\section{Dolomitization}

This process followed by generating fine-crystalline $(<20$ microns) and medium-crystalline (20-100 microns) and coarse-crystalline (20-400 microns) dolomites. This type of

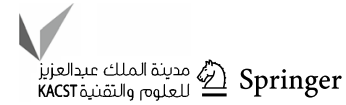


Fig. 5 The paragenetic sequence of diagenetic events of the Arab Formation. This diagram reveals diagenetic processes occurred in eogenetic and mesogenetic environments. Moreover, the effect of each diagenetic processes on reservoir quality is determined

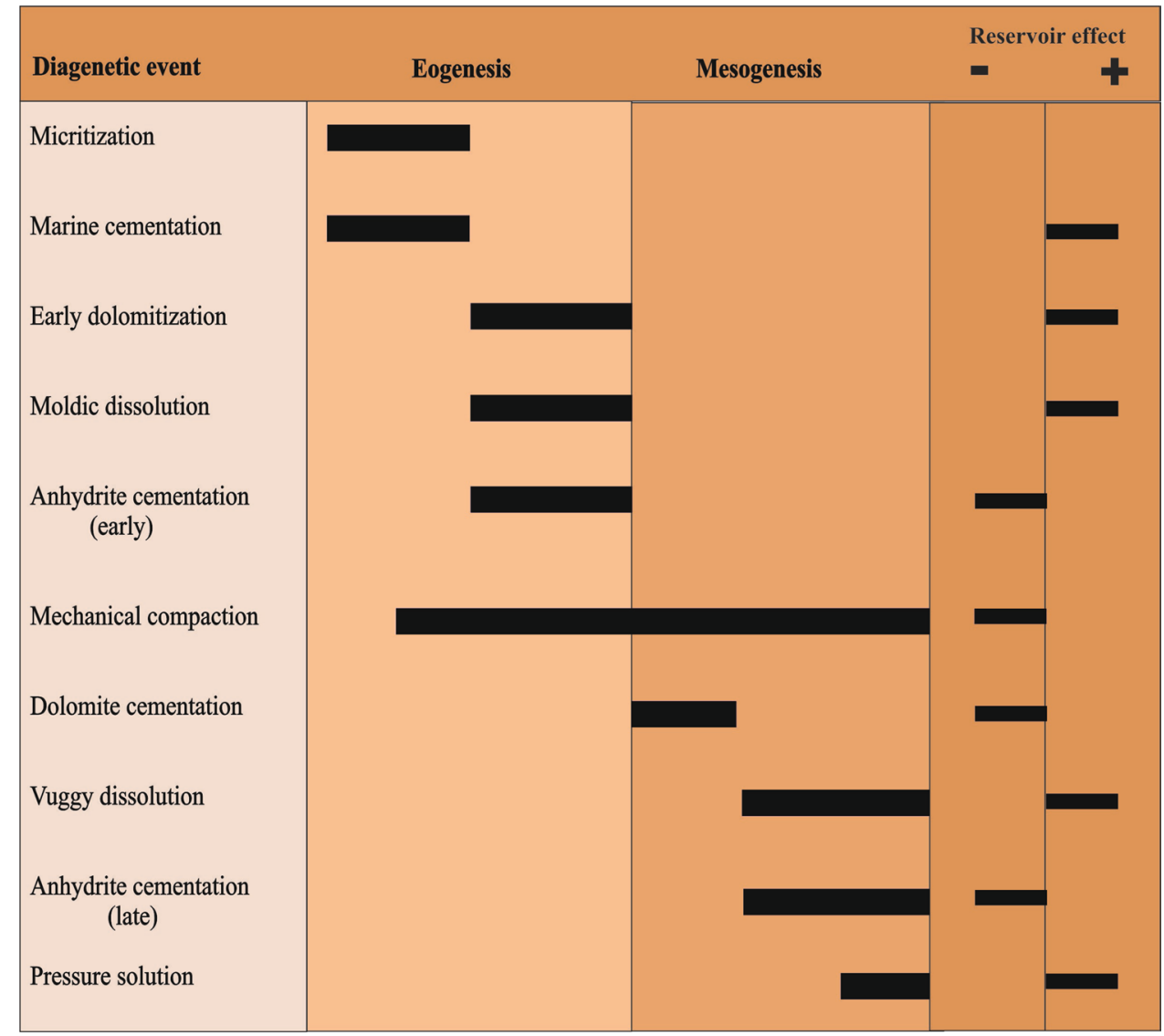

dolomite is prevailing in sequence B of B-01 and C-01 wells. Fine-crystalline dolomites formed in low-energy facies (F2 to F5) in the vicinity of evaporite deposits (Fig. 6a). In contrast, high-energy facies (F6, F7, and F8) had the potential to form medium-to-coarse-crystalline dolomites (Fig. 6b). Medium-to-coarse-crystalline dolomites predominantly make up sequence $\mathrm{A}$ and sequence $\mathrm{C}$ in the $\mathrm{B}-01$ and $\mathrm{B}-02$ wells as well as the large majority of B-02. In the studied successions, euhedral (planar-e) to subhedral (planar-s) (sensu Sibley and Gregg 1987) dolomite shapes are prevalent. The dolomites of the Arab Formation have values for oxygen isotope that range from -2 to $-0.8 \%$ PDB and carbon isotope that range from 1.2 to $3 \%$ PDB (Fig. 7).

The dolomite cement as overgrowth appeared in the form of limpid rims on the coarse-crystalline dolomite in the studied interval (Fig. 6c). Among different sequences of this formation, the sequences $\mathrm{A}$ and $\mathrm{C}$ are more severely affected by the dolomite cementation in all wells.

Interpretation Dolomitization pervasively influenced the Upper Arab Formation and dolomite crystals replaced carbonate successions during the early stages of diagenesis by reflux of hypersaline fluids (Fig. 5) (Cantrell et al. 2001; Swart et al. 2005; Morad et al. 2012). The dolomite crystal shape is another factor controlling the reservoir properties. As a result of variations in the crystal size, pore spaces and pore connectivity are variable in these facies. Likewise, fine-grained crystals show low pore connectivity while the formation of large crystalline dolomite leads to the enhancement of porosity and permeability network (Fig. 6a, b). Most dolomites in the Arab Formation show euhedral shape seemingly are primary (e.g., Sharifi-Yazdi et al. 2019). Generally, the morphology of dolomite depends on temperature so that planar dolomite belongs to low-temperature conditions and by increased temperature, early dolomite boundaries would be destroyed. The relatively heavy $\delta^{18} \mathrm{O}$ values suggest these dolomites formed in the near surface diagenetic conditions (low-temperature conditions) (Fig. 7). This mechanism is correlatable with the other studies in the Arabian Platform (Azer and Peebles 1995; Morad et al. 2012; Sfidari et al. 2018). Incidentally, relatively heavy $\delta^{13} \mathrm{C}$ values are an indicator of the absence of durable exposure (Swart et al. 2005; Esrafili-Dizaji and Rahimpour-Bonab 2013).

Dolomite cement that formed in shallow burial conditions (Fig. 5) has a remarkable role in decreasing reservoir quality (Clark et al. 2004; Assadi et al. 2018). In addition to pore spaces occluding by this type of cement (Jones and Xiao 2005; Kordi et al. 2016), pore-throat was also plugged (Fig. 6c). In the Upper Arab carbonate, while dolomite cements are mainly intact, the dolomite crystals are largely dissolved out leading to reservoir improvement. 

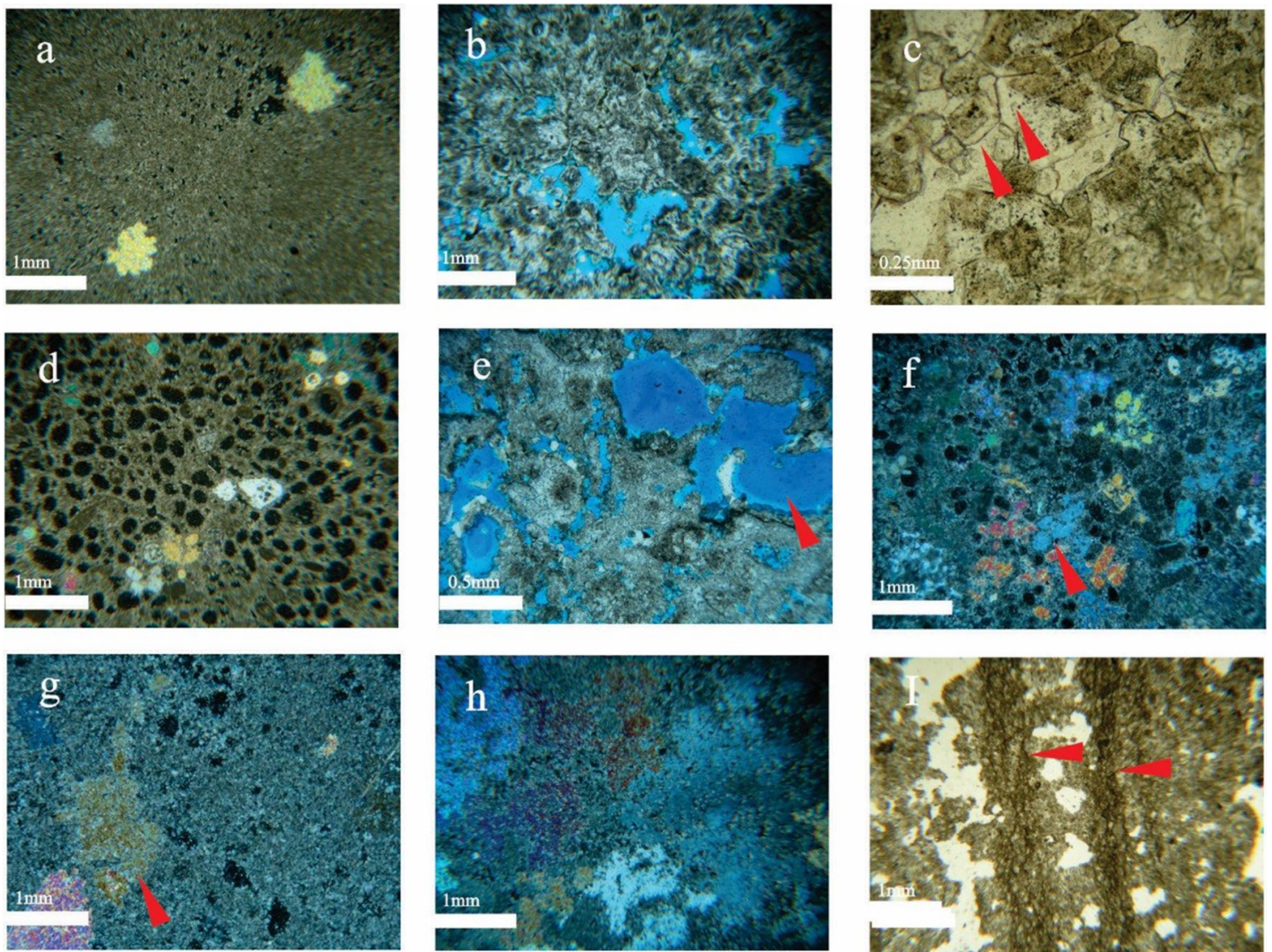

Fig. 6 Diagenetic features in the Arab successions. a Fine-crystalline dolomites were formed in mud-dominated facies, $\mathbf{b}$ medium-tocoarse-crystalline dolomites were formed in grain-dominated facies, c dolomite cementation in grain-dominated facies, $\mathbf{d}$ moldic disso-

\section{Dissolution}

Dissolution in the Arab dolomites occurs as moldic and vuggy porosity. An increase in abundance of moldic porosity is visible at the sequence $\mathrm{B}$ and less commonly in sequence $\mathrm{A}$, whereas it is almost absent in sequence C. Some of these pores were plugged by anhydrite cement (Fig. 6d). Vuggy dissolution, as non-fabric selective, occurs in dolomites of the Upper Arab Formation (Fig. 6e). This diagenetic feature pervasively cross-cut different facies and even previous diagenetic events (such as dolomite and dolomite cement). This dissolution occurs as two types including separate- and touching-vug pore spaces.

Interpretation Moldic dissolution as a primary diagenetic phase (Fig. 5) (Clark et al. 2004; Morad et al. 2012; Daraei et al. 2014; Beigi et al. 2017) occurred by dissolution of metastable components and led to the porosity enhancement in the grain-dominated facies (Fig. 6d). Concurrently, finecrystalline dolomite precipitated as intergranular cement in these facies. Customarily, the separate-vugs increased porosity, whereas touching-vug pores improved both porosity and lution, e vuggy dissolution, $\mathbf{f}$ pore-filling anhydrite cementation, $\mathbf{g}$ poikilotopic anhydrite cementation, $\mathbf{h}$ pervasive anhydrite cementation and $\mathbf{i}$ stylolitization in mud-dominated facies

permeability of the Arab dolomites (Fig. 6e). Therefore, touching-vug which accompanied by the intercrystalline porosity is crucial parameters that have controlled the Upper Arab Formation reservoir quality. Apart from this, vuggy porosity was created by basinal fluids in mesogenetic realm (Fig. 5) (Sharifi-Yazdi et al., 2019).

\section{Anhydrite cementation}

The Arab Formation lacks calcite cement, and the most substantial cement is various types of anhydrite cement. Common forms of anhydrite cement include pore-filling, poikilitopic and pervasive (Fig. 6f, g, h). In some cases, anhydrite cement dissolved similarly to vuggy pores and caused reservoir improvement. Anhydrite cement is common in sequences A and B in the B-01and B-02 wells and sequence $\mathrm{A}$ in the $\mathrm{C}-01$ well.

Interpretation Anhydrite cementation is one of the most prevalent diagenetic processes in the Arab carbonate that significantly influenced reservoir properties (Clark et al. 2004; Assadi et al. 2018). Pore-filling cements plugged

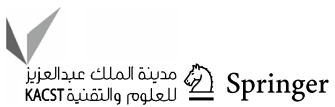




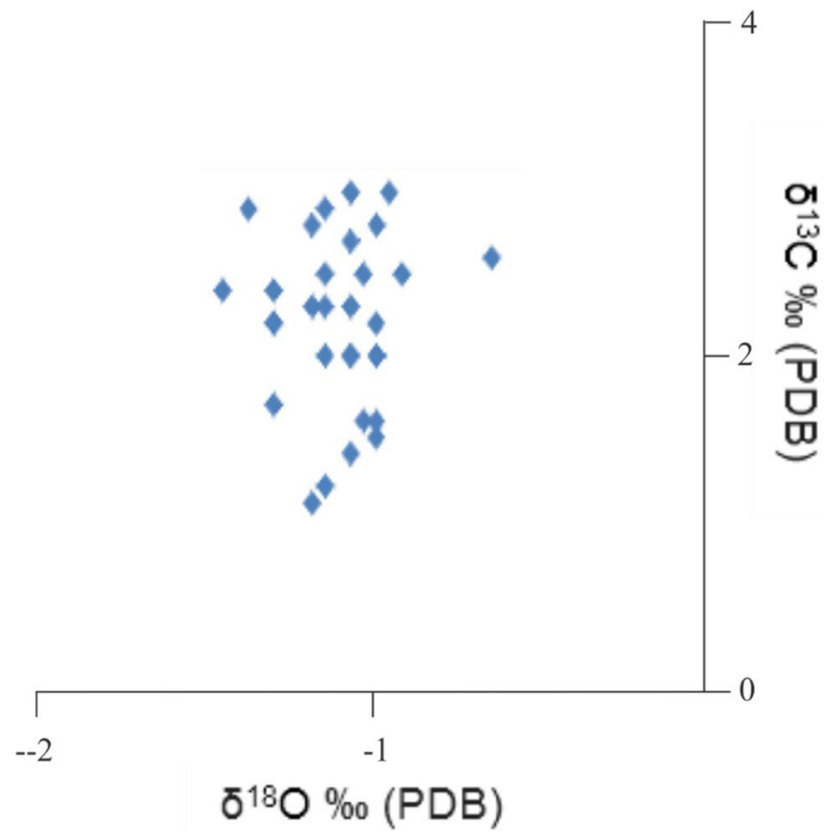

Fig. 7 Cross plot $\delta^{18} \mathrm{O}$ vs. $\delta^{13} \mathrm{C}$ shows near-surface precipitation of dolomite

moldic porosity and generally reduced porosity and permeability values during hypersaline diagenesis (Figs. 5, 6f). Late-stage anhydrite cementsas poikilotopic and pervasive occluded vuggy pore spaces (Fig. 6g). Considering this type of cement occluded the vuggy pore spaces, its formation could be ascribed to the late burial conditions (Fig. 5). Poikilotopic cement is responsible for the diminution of porosity values, and pervasive form exerts a destructive role in reservoir quality (Fig. 6h) (Lucia 2007).

\section{Compaction}

Low-amplitude stylolite overprints the diagenetic features (such as dolomites and anhydrite cements). Obviously, stylolites are seen in mud-supported facies (F2 to F5) along with fine-crystalline dolomite (Fig. 6i). This diagenetic feature is prevalent in sequence $\mathrm{C}$ of the B-01 and B-02 wells and the total interval of the $\mathrm{C}-01$ well.

Interpretation Compaction characterized by stylolite that is chiefly observable in mud-dominated facies in this formation (Fig. 6i) (Alsharhan and Whittle 1995; Al-Emadi et al. 2009; Morad et al. 2012). Indeed, overburden pressure induced the Arab reservoir and brought about the formation of stylolites in late burial stage (Fig. 5). It has played a barrier in the Arab carbonate so that is the main factor in permeability reduction. Despite its impact on reducing reservoir quality, open stylolites have occasionally led to reservoir improvement.

\section{Diagenetic model}

Considering diagenetic history, the Arab Formation experienced eogenetic and mesogentic realms (Alsharhan and Whittle 1995; Morad et al. 2012; Daraei et al. 2014; Sharifi-Yazdi et al. 2019) (Fig. 5). Eogenetic events include micritization, marine cementation, early dolomitization and fabric-selective dissolution. Diagenetic processes such as dolomite cementation, anhydrite cementation and chemical compaction occurred in the burial diagenetic realm. Here, the main diagenetic processes that influenced the Arab reservoir are detailed. Nevertheless, micritization has not had an explicit and momentous effect on reservoir characterization. Moreover, although marine cementation took place in the Arab interval and created a firm framework for allochems as a positive reservoir characteristic (Daraei et al., 2014), this diagenetic feature is not visible in the studied area as a result of the existence of dolomite crystals which imprinted on marine cement.

\section{Reservoir quality}

Generally, heterogeneity in carbonate reservoir is forged by the geological context including depositional, diagenetic and pore characterizations which influenced FZI values (Burrowes et al. 2010; Enayati-Bidgoli et al. 2014; Sfidari et al. 2014; Nabawy 2015). Here, using the normal cumulative probability of log FZI, numbers of hydraulic flow units could be determined (Abbaszadeh et al. 1996).

\section{FZI approach}

FZI (flow zone indicator) method was suggested by Amaefule et al. (1993) by modification of Kozeny (1927) and Carman (1937) equation:

$0.0314 \sqrt{\frac{k}{\Phi_{\mathrm{e}}}}=\left(\frac{\Phi_{\mathrm{e}}}{1-\Phi_{\mathrm{e}}}\right)\left(\frac{1}{\sqrt{F_{\mathrm{s}}} \cdot \tau \cdot S_{\mathrm{g}}}\right)$

RQI is reservoir quality index $(\mu \mathrm{m})$ :

$\mathrm{RQI}=0.0314 \sqrt{\frac{k}{\Phi}}$

$\Phi z$ is normalized porosity:

$\Phi z=\left[\frac{\Phi}{1-\Phi}\right]$

FZI $(\mu \mathrm{m})$ is flow zone indicator:

$\mathrm{FZI}=\left[\frac{1}{\sqrt{F_{\mathrm{s}}} \cdot \tau \cdot S_{\mathrm{g}}}\right]$ 
Then, by taking logarithm from Eq. (1) below equation is gain:

$\log (\mathrm{RQI})=\log \left(\Phi_{z}\right)+\log (\mathrm{FZI})$

here based on inflection points, four HFUs were recognized in which reservoir quality elevated from HFU4 to HFU1 (Fig. 8). Geological and petrophysical features of each HFU catalog are indicated (Table 2).

HFU4 with an average of $18.09 \%$ porosity and $1.14 \mathrm{mD}$ permeability, this unit mainly contains mud-dominated facies (F2, F3, and F5) belonging to intertidal and lagoon settings (Fig. 9a). The most important pore type in this unit is vuggy porosity that mainly occluded by cementation along with stylolitization. This unit has been developed in early TST at sequence A, TST at sequence B and early TST/late HST at sequence C.

HFU3 here the average porosity and permeability values are $17.84 \%, 13.71 \mathrm{mD}$, respectively. The predominant facies are lagoon (F5) and leeward shoal facies (F6) as well as mudstone and grainstone facies with high frequency (Fig. 9b). Moldic and then vuggy porosity are prevalent pore types in this unit. This HFU is frequent in the middle TST at sequence A, middle HST at sequence B and late TST/early HST at sequence C.

HFU2 this hydraulic flow unit has $16.94 \%$ porosity and $75.4 \mathrm{mD}$ permeability and with grain-dominated facies assigned to shoal environment (F7, F8), which are the major constituent of HFU2 (Fig. 9c). Intercrystalline and then vuggy porosity (touching-vug) are the most significant pore spaces. HFU2 is partly developed in early HST/late TST at sequence A, early HST at sequence B and HST at sequence $\mathrm{C}$.

HFU1 with $17.73 \%$ porosity and $393.53 \mathrm{mD}$ permeability consists of grainstone facies belonging to shoal setting (F7, F8) with high porosity and permeability (Fig. 9d). Vuggy porosity (touching-vug) and then intercrystalline porosity are predominant in this unit. This flow unit is observed in early HST at sequence A and partly at the sequence, B. Porosity is dominated by vuggy pore spaces in this reservoir unit that caused reservoir improvement.

\section{Lucia classification}

Although the hydraulic flow unit is known as a homogenous interval, high heterogeneity within the Arab carbonate reservoir resulted in variations in the reservoir properties.
Fig. 8 Probability plot of FZI reflects four hydraulic flow units in the studied wells

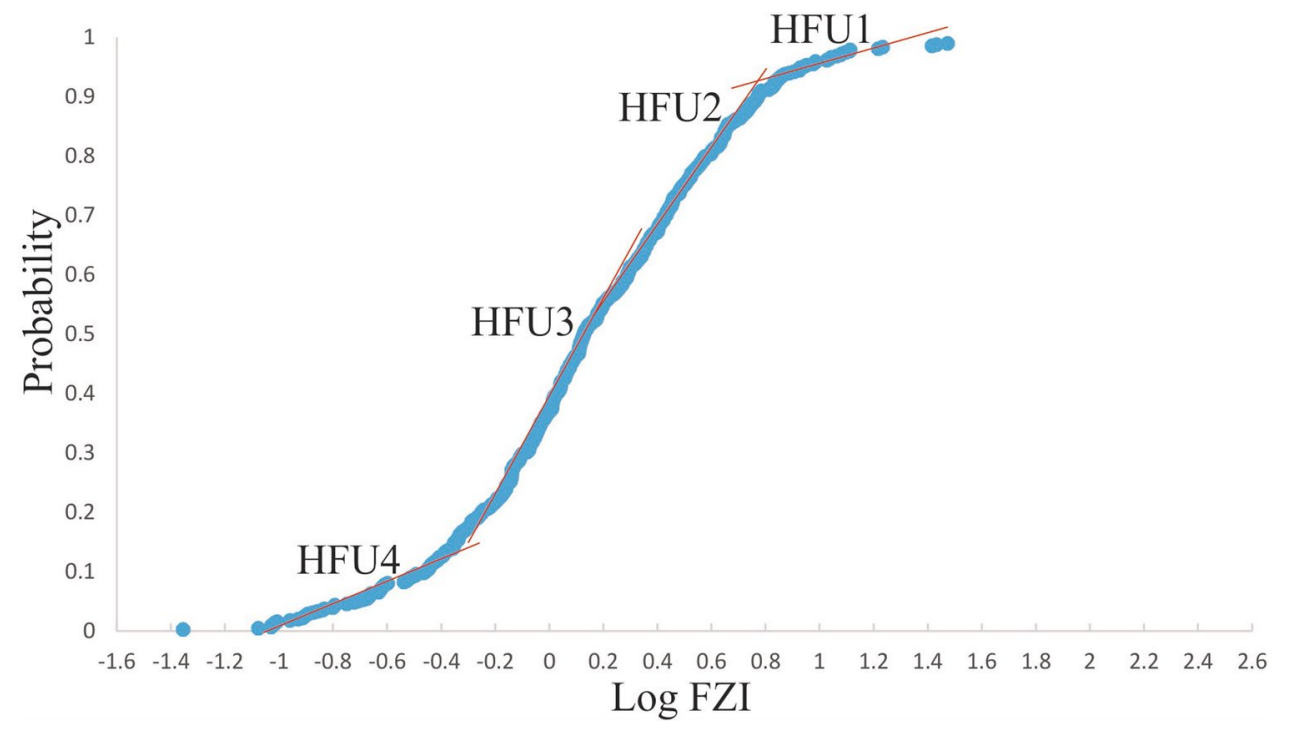

Table 2 Depositional, diagenetic, sequence positions, pore type and petrophysical attributes of hydraulic flow units

\begin{tabular}{|c|c|c|c|c|}
\hline HFUs & Depositional features & Diagenetic processes & Sequence position & Pore type \\
\hline HFU1 & Mainly grain-dominated facies & $\begin{array}{l}\text { Coarse-crystalline dolomitizationvuggy } \\
\text { dissolution }\end{array}$ & Mainly late TST, early HST & Intercrystalline, Touching-Vug \\
\hline HFU2 & Mainly grain-dominated facies & Coarse-crystalline dolomitization & Mainly late TST, early HST & Intercrystalline \\
\hline HFU3 & Wacke-pack facies & $\begin{array}{l}\text { Moldic dissolution, anhydrite cementa- } \\
\text { tion, dolomite cementation }\end{array}$ & Early TST, late HST & Moldic, Intercrystalline \\
\hline HFU4 & Mud-dominated facies & $\begin{array}{l}\text { Anhydrite cementation, stylolitization, } \\
\text { dissolution }\end{array}$ & Mainly early TST, late HST & Moldic \\
\hline
\end{tabular}


Fig. 9 The frequency of various facies in each HFU including MDST: mudstone facies (F1, F2), WKST-PKST: wackestonepackstone facies (F4, F5, and F6) and GRST: grainstone facies (F7, F8)

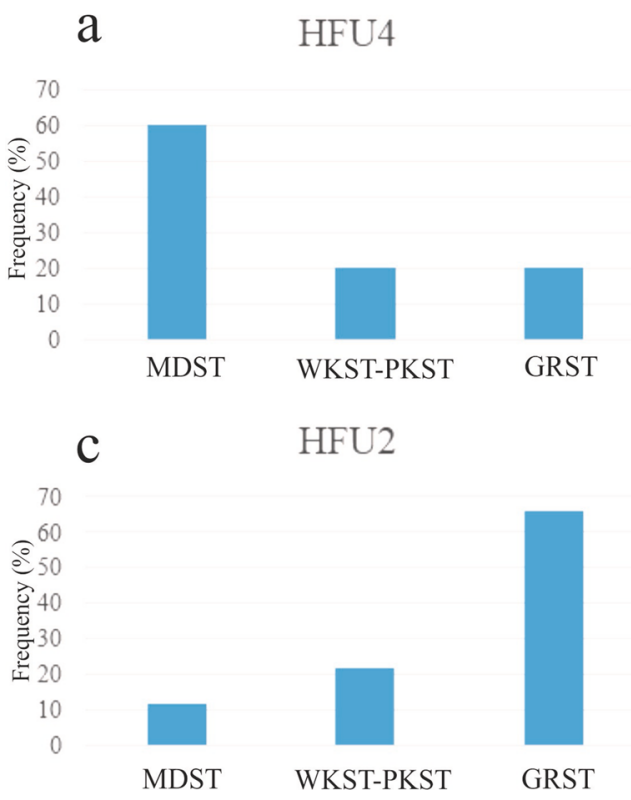

Hence, it is essential to classify each HFU using geological and petrophysical features in detail. Lucia classification (sensu Lucia 1995, 2007)is assigned to carbonate succession for classifying them based on the same fabric in a petrophysical framework. This approach is helpful for grouping samples that have analogous geological features, especially diagenetic processes. Recognized hydraulic flow units with similar depositional and diagenetic characters demonstrate specified position on this diagram (Fig. 10). The Lucia classification scheme could illustrate diagenetic evolution and sedimentary fabric which is a useful approach for the prediction of reservoir improvement or deterioration. Accordingly, four HFUs were plotted on the Lucia diagram, reflecting various positions of HFUs because of variations in pore spaces and pore-throat size. Class 3in Lucia diagram mainly comprises HFU4 and HFU3 with mud-dominated nature. Class 2 contains a part of HFU3 with grain-dominated nature and
HFU2 facies. Class 3 chiefly encompasses HFU1 that comprises grain-dominated facies. In spite of depositional fabric effects on different HFUs, diagenetic evolution caused alterations of porosity and permeability values. Thus, diagenetic alterations are the basic controls in the positions of the Lucia classes.

\section{Mercury injection capillary pressure (MICP) analyses}

\section{Pore-throat size distribution}

Pore-throat radius obtained using the Laplace equation after the differentiation gives pore-throat size distribution (PTSD) (Hosseini et al. 2018; Nazemi et al. 2019). For each porethroat size, the numbers obtained from PTSD are between 0 and 1.0. In fact, PTSD is a fractional graph of the pore volume injected (v) against pore-throat radius (Fig. 11).
Fig. 10 Lucia classification scheme used as a template to illustrate the identified HFUs in this study. As shown, groups of facies which belong to a specific HFU could be justified by Lucia's scheme, considering their depositional features and diagenetic imprints

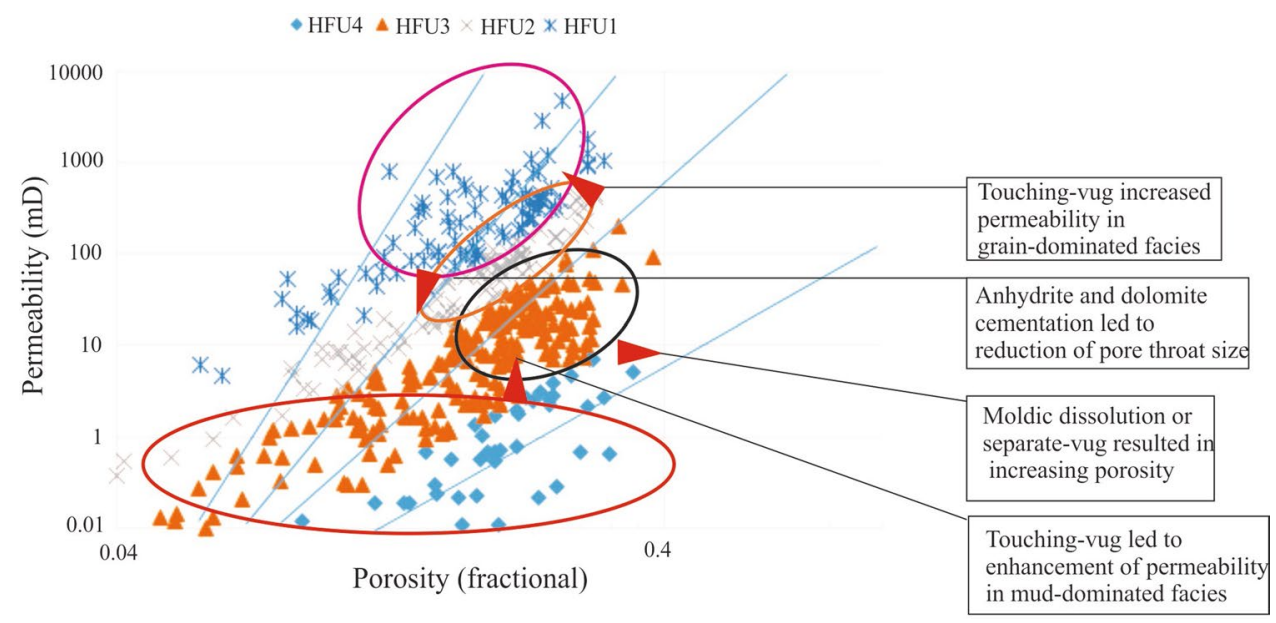


HFU1
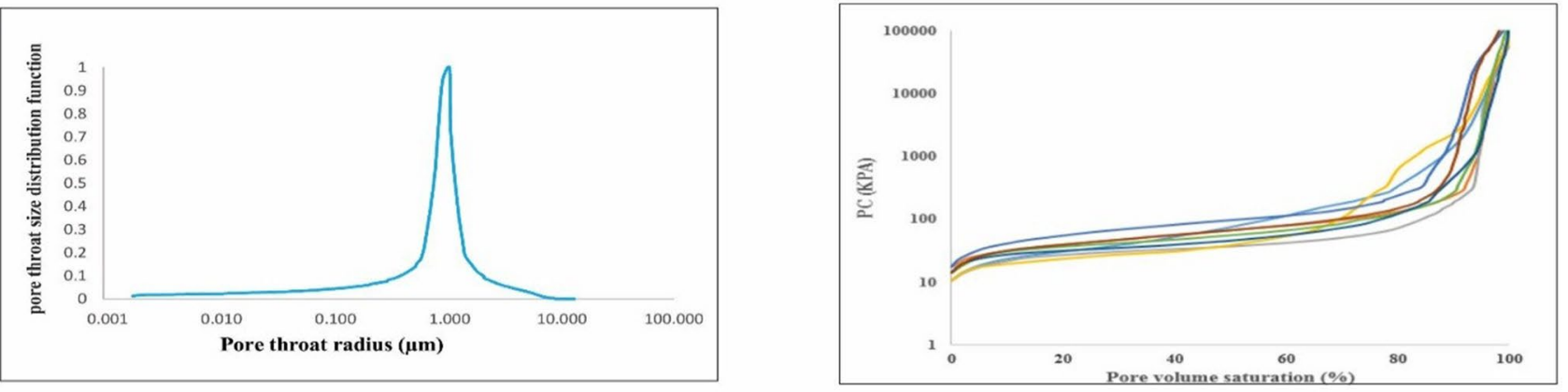

HFU2
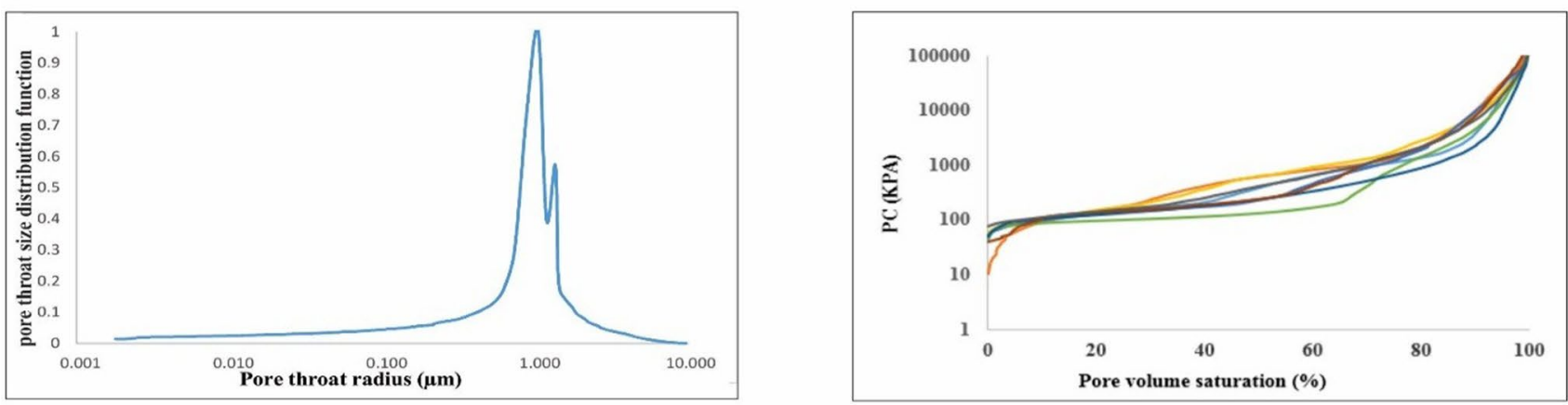

\section{HFU3}
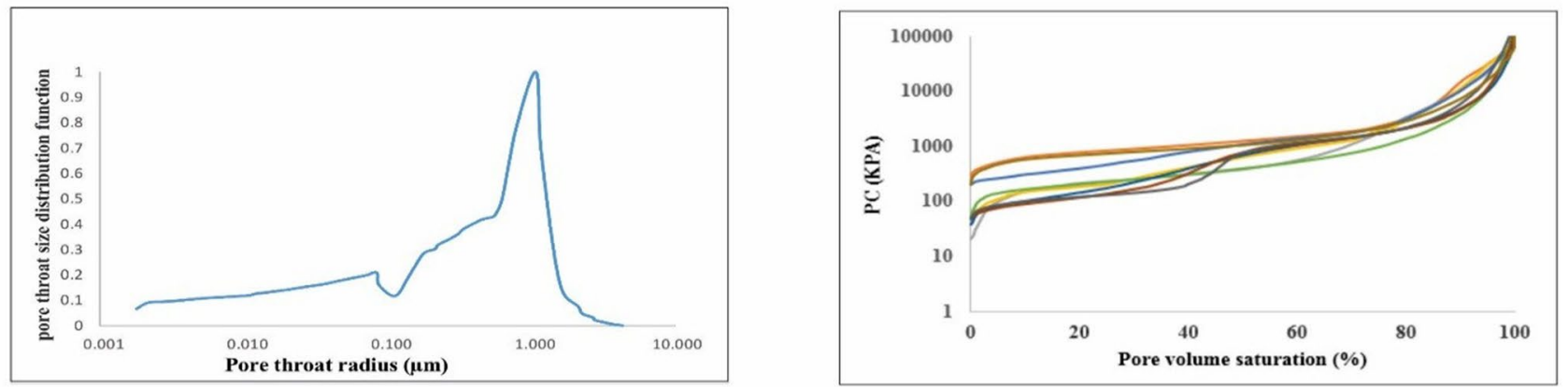

\section{HFU4}
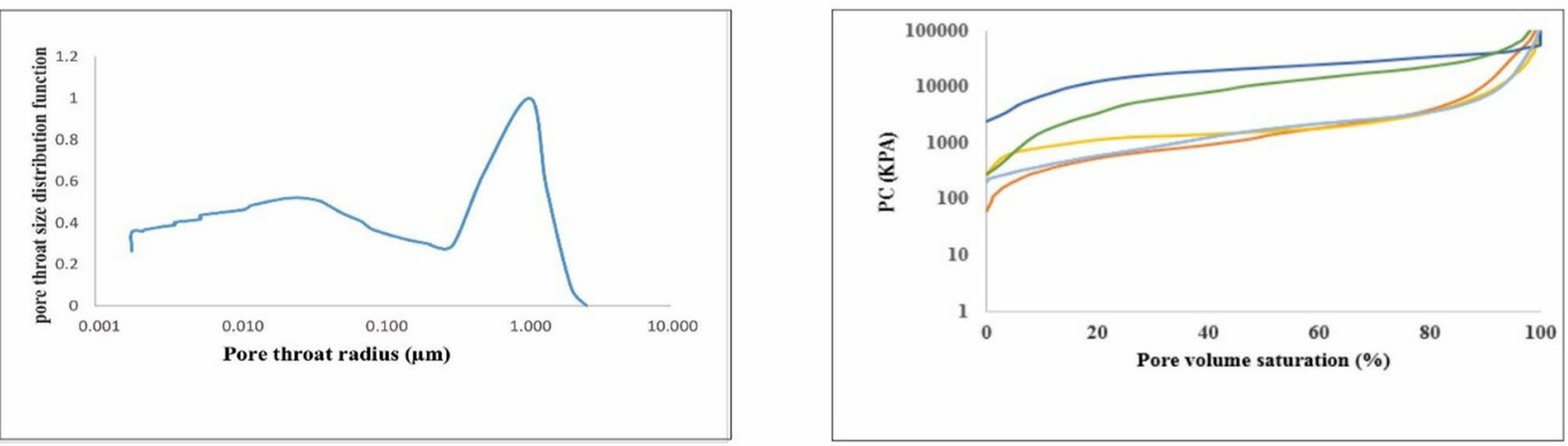

Fig. 11 PTSD plot for different HFUs 


$$
\text { PTSD }=\mathrm{d} v / \mathrm{d} \log (r)
$$

where $r$ is the pore-throat size in micron and $v$ is pore volume injected (fractional). The pore-throat size is divided into macropore throats $(>1.5 \mu \mathrm{m})$, mesopore throats $(1.5-0.5)$ and micropore throats $(<0.5 \mu \mathrm{m})$ groups using the normalized pore-throat size distribution function. The PTSD is normalized using the equation:

Smoothing : $\mathrm{PTSDi}=(\mathrm{PTSDi}-1+2 \mathrm{PTSDi}+\mathrm{PTSDi}+1) / 4$

PTSD normalized $=$ PTSDi $/$ PTSD $\max$

\section{HFUs characterization and interpretation}

For assessment of heterogeneity in the carbonate reservoir, the FZI method by the establishment of a relationship between porosity and permeability introduces homogenous units (Hearn et al. 1984; Tavakoli et al. 2011). These units are controlled intensely by the geological context including depositional and diagenetic attributes. These geological attributes led to improvement or reduction in pore connectivity. Although the primary properties of reservoir rocks determined by the depositional background, reservoir evolution is governed by the diagenetic processes. Owing to the occurrence of multiple diagenetic phases, reservoir evolution was dictated by factors that increase or decrease the porosity and permeability.

Among other hydraulic flow units, HFU4 is predominantly composed of mud-dominated facies (Fig. 9). Diagenetic features such as fine-crystalline dolomitization, stylolitization and drastic anhydrite cementation led to a reduction in porosity and permeability at Class 3 of Lucia (Fig. 10). Cemented grain-dominated facies (F7, F8) with low frequency occluded by the pervasive anhydrite cement shows low reservoir quality because this type of cement plays a vital function in occluding both pore spaces and pore throat size (Lucia, 2007). Wackestone-packstone facies (F4, F5, and F6) has chiefly low porosity and permeability (Fig. 8); however, moldic pores caused increasing porosity, occasionally. Indeed, the greatest contribution of moldic porosity in reservoir quality is the enhancement of isolated pore types has only a positive influence on porosity. Although dolomite crystals are replaced in these facies, fine-crystalline dolomite in the form of cement-filled intergranular spaces reflecting decreasing the permeability. Mudstone facies (F2) in this HFU has not significant diagenetic features in line with the improvement in reservoir characterization such as dissolution. According to the mercury injection capillary pressure data, one of the main characteristics of this HFU is a drastic dispersion of the pore-throat size and pores. Despite the low slope of the injection curves and the presence of the flat part at the middle, the pressure of the mercury entering the permeable network is the highest level compared to other HFUs (Fig. 11). The pore-throat size distribution diagram exhibits a high expansion and tendency toward smaller radius. Diagenetic imprints contribute largely to destruction reservoir quality especially permeability in HFU4. However, some diagenetic events like leaching led to an increase in porosity. HFU3is mainly composed of wackestone-packstone facies (F4, F5 and F6) (Fig. 9) in a various range of permeability at Class 2 of Lucia. Pervasive anhydrite cement is a prevalent diagenetic attribute that has a negative effect on both parameters including porosity and permeability (Fig. 8). Dolomite cement in grain dominated facies is less important that also plays the same role as the anhydrite cement. These diagenetic modifications led to the destruction of the pore connectivity (lesser $1 \mathrm{mD}$ ) in facies that are similar to HFU4. In comparison with HFU4, facies with permeability from 1 to $10 \mathrm{mD}$ endured porefilling anhydrite cementation in which porosity values are reduced. The dissolution influenced wackestone-packstone facies in this HFU by the creation of touching-vug pores that increased the permeability from 10 to $100 \mathrm{mD}$ (Fig. 10). The mercury injection curves of HFU3 illustrate a higher pressure than HFU1 and HFU2 at the entrance point of mercury into the porous network (higher pressure displacement) (Fig. 11). In other parts of the capillary pressure-saturation curves, the gradient reflects the pore-throat connection with low conjunction, radius and poor sorting. Based on the pore-throat size distribution curve, the pore-throat radius of more than 1 micron is rare in this class and pore-throats are more likely to have a lower radius. The pore-throat radius of HFU3 is smaller than the other introduced HFUs (HFU1 and HFU2). Consequently, this HFU has low reservoir quality due to the presence of micrite and diagenetic imprints such as pervasive anhydrite cement and dolomite cement. Despite this, dissolution brought about the formation of vuggy porosity in mud-dominated facies and improved permeability. Apart from pore space, this pore type has a positive effect on pore-throat connection.

In HFU2 grainstone facies (F7, F8) have a higher frequency (Fig. 9) and are protected from dissolution and anhydrite cementation locating at class 2 of Lucia (Fig. 10). Intercrystalline porosity (due to the presence of coarse-crystalline and euhedral dolomite) is predominant in these facies with permeability between 10 and $100 \mathrm{mD}$. Influence of coarsecrystalline dolomite on reservoir improvement in the Arab dolomites was also introduced from the other Arabian Plate areas (Al-Saad and Sadooni 2001; Cantrell et al. 2001; Daraei et al. 2014). The presence of high-energy grainstone facies provided a proper circumstance to induce coarsecrystalline dolomitization through the hypersaline diagenetic fluid (Morad et al., 2012; Sharifi-Yazdi et al., 2019). In addition to the function of such dolomites in the improvement in 
porosity, the large size of them (100-500 microns) dramatically enhanced permeability of grainstone facies. Generally, in this HFU, the mercury-injection curves illustrate higher pressure at the entrance point of mercury into the porous network and at different points of saturation, compared to the introduced HFU1. These features exhibit a lower porous network quality, weaker continuity, smaller radius of porethroats and inferior sorting than HFU1. The middle part of the mercury injection curves in this category shows a slope (Fig. 11). According to the pore-throat size distribution diagram, some increase in the sorting and decrease in the porethroat radius distribution in the facies of this category are concluded. The presence of touching-vug accompanied by coarse-crystalline dolomite led to an increase in pore throat size and permeability values more than $100 \mathrm{mD}$ in HFU1 (Fig. 8). Dissolution caused touching-vug porosity in graindominated facies (F7, F8), and these are located in class 1 Lucia (Figs. 8, 10). In other words, touching-vug dissolution boosted pore-throats size of grainstone facies. The MICP studies in this HFU (comparing to the other HFUs) indicating that the curves of this category are characterized by a much lower pressure at the mercury entering point and in contrast higher saturation levels at similar pressures. These features demonstrate greater connectivity, larger grain size, more sorting and generally higher quality pore-throat network than the other HFUs (Fig. 11). The middle part of the mercury injection curves in the HFU1 displays a slight slope. By examining the pore-throat size distribution curve, the great increase in sorting and the decrease in the porethroat radius distribution in this HFU can be observed.

\section{HFUs in a sequence stratigraphic framework}

Morad et al. (2012) concluded that the reservoir quality of Arab-C was controlled by the dolomitization and dissolution of anhydrite cement. Clark et al. (2004) revealed that dolomitization has a striking influence on permeability and capillary pressure properties in the Upper Arab Formation. Daraei et al. (2014) and Assadi et al. (2018) in their studies display high reservoir quality belongs to high-energy shoal facies in HST.

In this study, sequence stratigraphic framework is used as a conceptual model for reservoir characterization (Fig. 12). Owing to the sensitivity of HFUs to multiple diagenetic stages in various wells, correlation is a complicated process. Sequence stratigraphy is known as an approach which is able to identify correlatable units. In spite of the importance of the vertical distribution of HFUs, considering their lateral distribution also has critical significance. It results in the identification of factors governing reservoir quality in interfield and intra-fields scales.

The sequence A in early HST and late TST mainly encompasses HFU1, because of the presence of coarse-crystalline dolomite and intense vuggy dissolution. The most important factor in the reduction in reservoir quality is dolomite cementation, and to a lesser extent anhydrite cementation in this sequence. Dolomite cement is the most considerable factor in the pore connectivity decline in B-01 well, whereas anhydrite cements have been developed as a negative major factor in the other wells. Early TST and late HST developed with poor HFUs and low thickness.

Sequence B that containing various facies (mud-dominated to grain-dominated facies) has considerable HFU3 and HFU4 at late TST and early HST. This facies diversity led to the distribution of various HFUs. However, touchingvug resulted from dissolution along with coarse-crystalline dolomite, caused local permeability increase in Field-R. A similar condition in terms of depositional and diagenetic features is seen at late HST of sequence $\mathrm{C}$ and early TST in sequence B. Accordingly, it governed by low reservoir quality HFUs.

Sequence C chiefly composed of coarse-crystalline dolomite but it does not represent high reservoir quality. In this sequence, anhydrite cementation is a major factor in occluding pore-throats. Dolomite cement also performed as a minor factor in the reduction in reservoir properties. In terms of sequence stratigraphy, HFU4 with poor reservoir quality principally belongs to late HST and early TST. The HFU3 with moderate-to-poor reservoir quality has been found at the middle TST and middle HST. Conversely, HFU1 and HFU2 with high reservoir quality are assigned to late TST and early HST that includes high energy facies. In general, the lateral distribution of hydraulic flow units reveals that high HFUs (HFU1 and HFU2) have an increasing trend from Field-B to Field-R. This is due to the development of touching-vug dissolution in C-01 well. Sedimentological $\log$ in a sequence stratigraphic framework belongs to B-01 well as illustrated in Fig. 13. Correlation between the studied wells based on stratigraphic properties and hydraulic flow units within the third-order sequence stratigraphic scheme is shown in Fig. 14.

\section{Conclusions}

Based on the integration of microfacies analysis, diagenetic history, sequence stratigraphy and petrophysical properties, a basic model established for the Arab reservoir. Accordingly, eight sedimentary facies were recognized that deposited in a ramp-type platform during the Late Jurassic. Dolomitization, dissolution, cementation and compaction are major diagenetic phases that have significantly influenced the Arab reservoir. In order to reduce the heterogeneity of the reservoir, HFUs were determined using the FZI method. Then, recognized HFUs (HFU1 to HFU4) are integrated with geological, petrophysical (Lucia's classification)

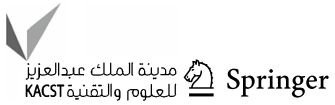




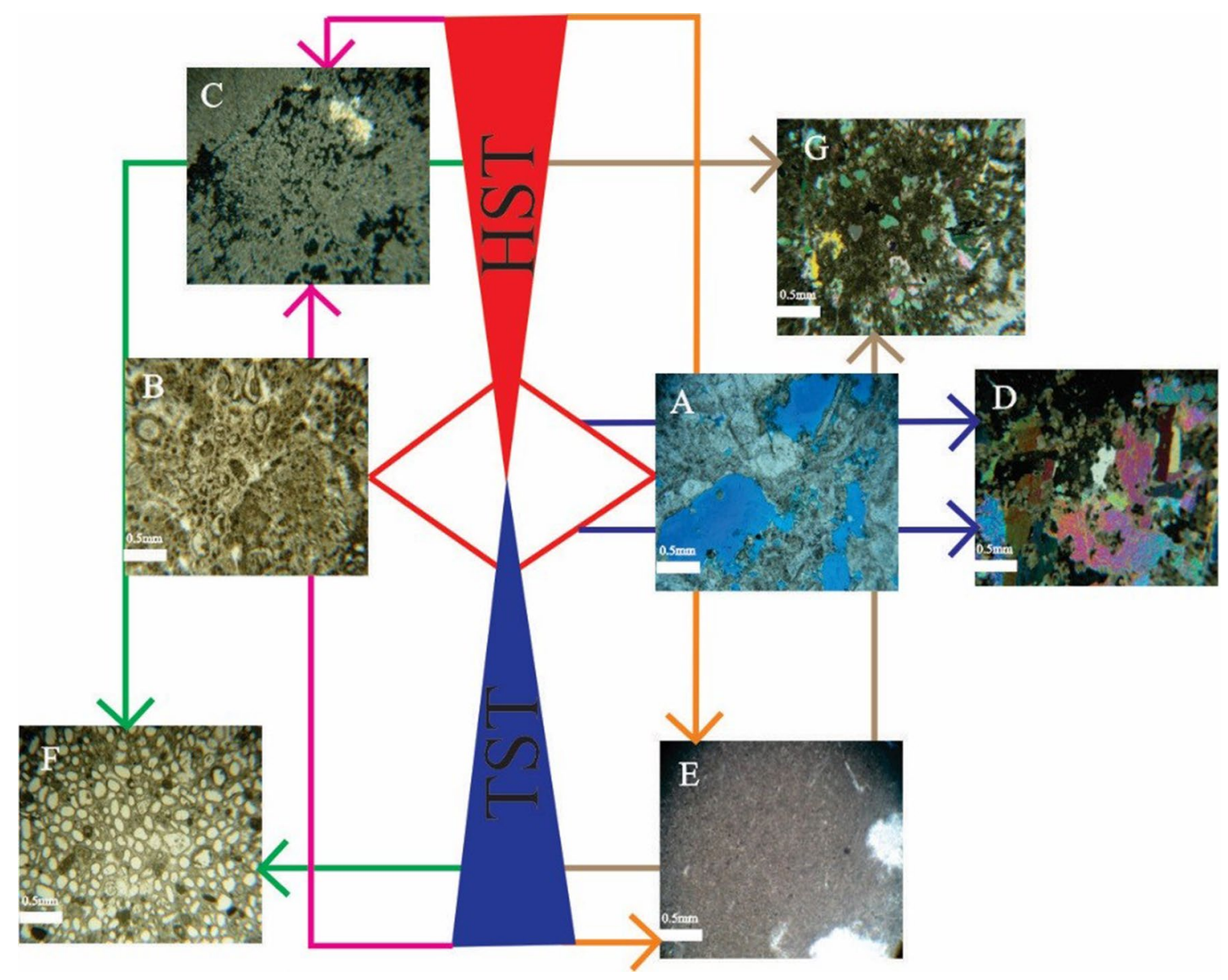

Fig. 12 Sequence position of various HFUs. a HFU1: vuggy grainstone facies at late TST or early HST, b HFU2: grainstone facies at late TST or early HST, c HFU3 with mudstone facies has permeability $10-100 \mathrm{mD}$ at early TST or late HST, d HFU3 and HFU4: cemented grainstone facies has permeability lesser $10 \mathrm{mD}$ at late TST or early HST, e HFU3and HFU4: mudstone facies has permeability lesser $10 \mathrm{mD}$ at late TST or early HST, f HFU4: wackestone-packstone facies with high porosity and low permeability at middle TST or middle HST, g HFU4: cemented wackestone-packstone facies with low porosity and permeability at middle TST or middle HST within the sequence stratigraphic framework of the field. HFU1 includes the higher reservoir quality intervals with high pore connectivity and composed of grain-dominated facies (coarse-crystalline and euhedral dolomite) that was subjected to vuggy dissolution. This HFU is predominantly found at the late TST and early HST. Depositional features of HFU2 show similarity with the previous HFU, but encompass grain-dominated facies with lesser diagenetic alterations at the late TST and early HST. HFU3 mostly includes mud-dominated facies with fine-crystalline dolomite with weak permeability located in the middle TST and middle HST sequence positions. Factors such as compaction and cementation diminished pore connections. However, touching-vug was a positive feature for increasing permeability in mud-dominated facies. Tight grainstone facies influenced by cementation is included in this HFU. HFU4 has the lowest reservoir quality because of the domination of mud-dominated facies, cementation and/or stylolitization. Moldic dissolution is the principal factor in increasing porosity in the wackestone-packstone facies within HFU3 and HFU4. Incidentally, sequence stratigraphic position of HFU4 is mainly observable at the early TST and late HST. Generally, dolomitization and dissolution (touching-vug) have major impacts on reservoir improvement in the studied area. In conclusion, this research reflects the importance of diagenetic history reconstruction to deduce the heterogeneity of the Arab reservoir. Accordingly, by integrating various approaches, including petrophysical methods in a sequence stratigraphic framework, a conceptual reservoir model is produced. In fact, although depositional facies builts the internal and external architecture of the Arab carbonate, diagenetic fluids created under the warm and arid climate has brought about a wide range of modifications that determine reservoir quality of this succession. 


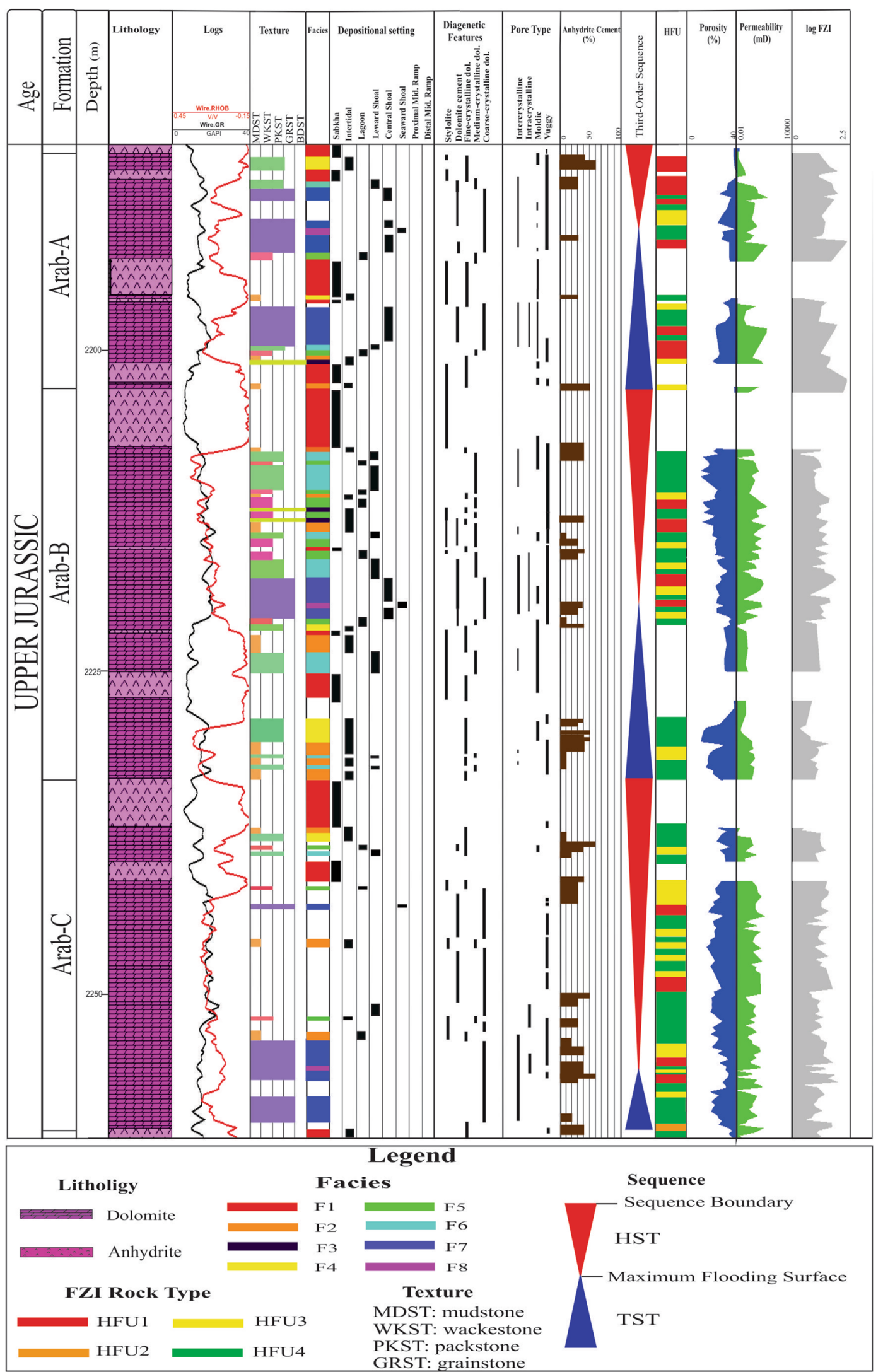

Fig. 13 Correlation between different parameters including depositional, diagenetic and HFUs in a sequence stratigraphic framework in B-01 well 


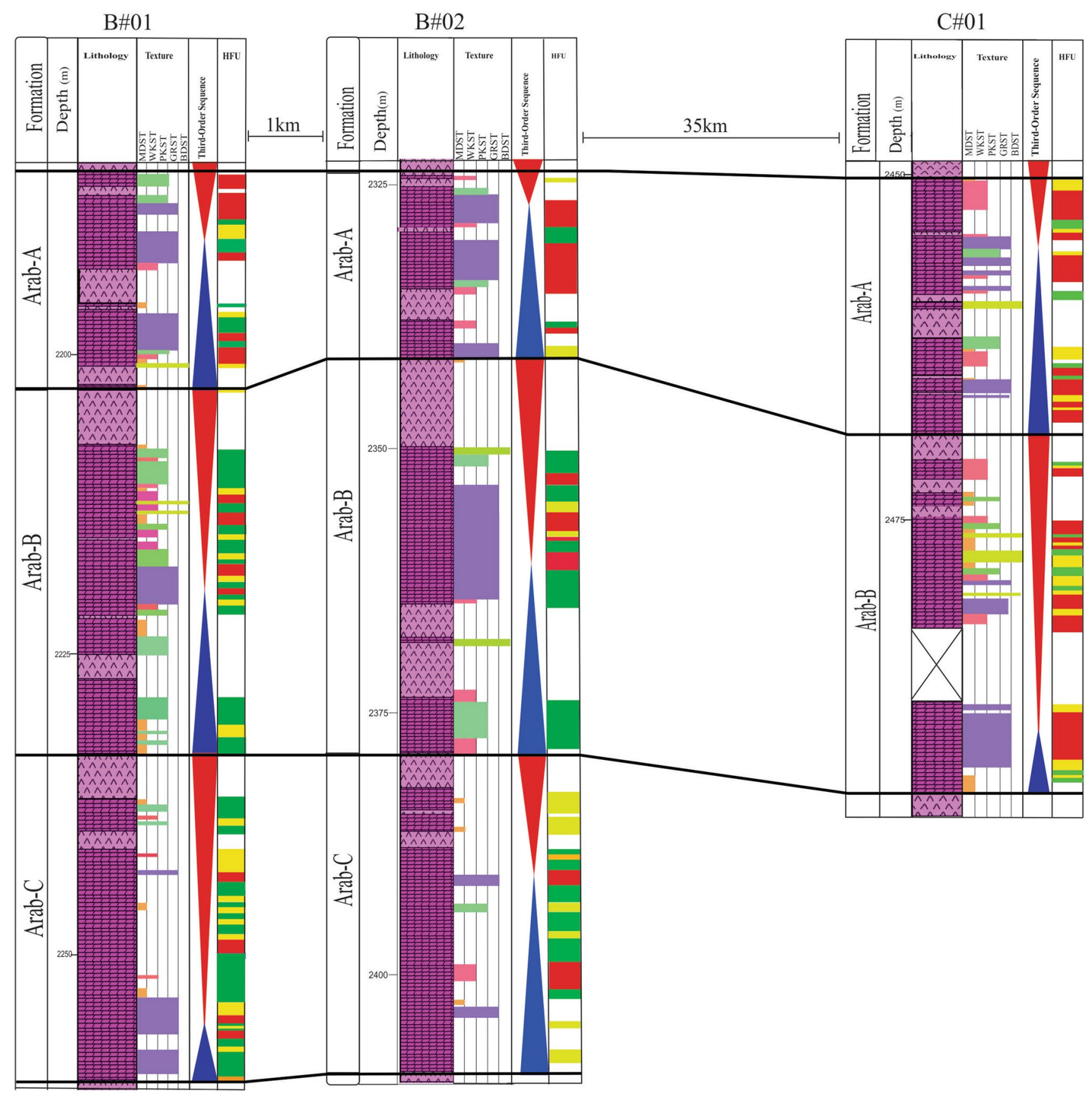

Fig. 14 Correlation among the studied wells based on stratigraphic properties and hydraulic flow units within a sequence stratigraphic framework

Acknowledgments The authors acknowledge the University of Tehran for providing facilities for this study. Iranian Offshore Oil Company (IOOC) is thanked for data preparation. Specific thanks are due to the reviewers of the paper Dr. Mohamed Khalifa and Dr. Mohamed Moustafa, who improved the paper with their beneficial comments and keen insight.

Open Access This article is licensed under a Creative Commons Attribution 4.0 International License, which permits use, sharing, adaptation, distribution and reproduction in any medium or format, as long as you give appropriate credit to the original author(s) and the source, provide a link to the Creative Commons licence, and indicate if changes were made. The images or other third party material in this article are included in the article's Creative Commons licence, unless indicated otherwise in a credit line to the material. If material is not included in the article's Creative Commons licence and your intended use is not permitted by statutory regulation or exceeds the permitted use, you will need to obtain permission directly from the copyright holder. To view a copy of this licence, visit http://creativecommons.org/licenses/by/4.0/. 


\section{References}

Abbaszadeh M, Fujji H, Fujimoto F (1996) Permeability prediction by hydraulic flow unitstheory and applications. Soc Pet Eng Form Eval 11:263-271

Ahr WM (2008) Geology of carbonate reservoirs: the identification, description, and characterization of hydrocarbon reservoirs in carbonate rocks. Wiley, Hoboken, pp 1-277

Al-Emadi A, Jorry SJ, Chautru JM, Caline B, Blum MS, Jeddaan N, Fryer V, Lèandri P, Fraisse Ch (2009) 3D modeling of the Arab Formation (MaydanMahzam Field, Offshore Qatar): an integrated approach. In: International Petroleum Technology Conference, Duha, International Petroleum Technology Conference 13461

Al-Husseini MI (2000) Origin of the Arabian plate structures: amar collision and Najd Rift. GeoArabia 5(4):527-542

Aliakbardoust E, Rahimpour-Bonab H (2013) Effects of pore geometry and rock properties on water saturation of a carbonate reservoir. J Petrol Sci Eng 112:296-309

Al-Saad H, Sadooni FN (2001) A new depositional model and sequence stratigraphic interpretation for the Upper Jurassic Arab "D" reservoir in Qatar. J Pet Geol 24(3):243-264

Alsharhan AS, Magara K (1995) Nature and distribution of porosity and permeability in Jurassic carbonate reservoirs of the Arabian Gulf. Facies 32:237-254

Alsharhan AS, Nairn AEM (1997) Sedimentary basin and petroleum geology of the middle east. Elsevier, Amsterdam

Alsharhan AS, Whittle GL (1995) Carbonate-evaporite sequences of the Late Jurassic, southern and southwestern Arabian Gulf. Am Assoc Pet Geol Bull 79:1608-1630

Amaefule JO, Altunbay M, Tiab D, Kersey DG, Keelan DK (1993) Enhanced Reservoir Description: Using core and log data to identify Hydraulic (Flow) Units and predict permeability in uncored intervals/wells. Society of Petroleum Engineers 26436

Assadi A, Rahimpour-Bonab H, Kadkhodaie-Ilkhchi R (2018) Integrated rock typing of the grainstone facies in a sequence framework: a case from the Jurassic Arab Formation in the Persian Gulf. Acta Geol Sin 92(4):1432-1450

Azer SR, Peebles RG (1995) Sequence stratigraphy of the Arab A to C Members and Hith Formation, Offshore Abu Dhabi. GeoArabia 3:251-268

Azer SR, Peebles RG (1998) Sequence stratigraphy of the Arab A to $\mathrm{C}$ members and Hith Formation, offshore Abu Dhabi. GeoArabia 3(2):251-268

Bates BS (1973) Oscar for an oilfield. Saudi Aramco World 24(6):14-15

Beigi M, Jafarian A, Javanbakht M, Wanas HA, Mattern F, Tabatabaei A (2017) Facies analyses, diagenesis and sequence stratigraphy of the carbonate evaporitesuccession of the Upper Jurassic Surmeh Formation: impactson reservoir quality (Salman Oil Field, Persian Gulf, Iran). J Afr Earth Sci 129:179-194

Burrowes A, Moss A, Sirju C, Pritchard T (2010) Improved permeability prediction in heterogeneous carbonate formations. Society of Petroleum Engineers, 131606

Buxton MWN, Pedley HM (1989) Short Paper: a standardized model for Tethyan Tertiary carbonate ramp. J Geol Soc 146(5):746-748

Cantrell DL (2006) Cortical fabrics of Upper Jurassic ooids, Arab Formation, Saudi Arabia: implications for original carbonate mineralogy. Sed Geol 186(3-4):157-170

Cantrell DL, Swart PK, Handford RC, Kendall ChG, Westphal H (2001) Geology and production significance of dolomite, ArabD reservoir, Ghawar Field, Saudi Arabia. GeoArabia 6(1):45-60

Carman PC (1937) Fluid flow through granular beds. Trans Inst Chem Eng 15:150-166
Chilingarian GV, Torbazadeh J, Metghalchi M, Rieke HH, Mazzullo SJ (1992) Interrelationships among surface area, permeability, porosity, pore size and residual water saturation, carbonate reservoir characterization: a geologic engineering analysis part 1, vol 30. Elsevier, Amsterdam, pp 379-397

Clark D, Heaviside J, Habib K (2004) Reservoir properties of Arab carbonates, Al-Rayyan Field, Offshore Qatar. Geol Soc Lond Spec Publ 235:193-232

Daraei M, Rahimpour-Bonab H, Fathi N (2014) Factors shaping reservoir architecture in the Jurassic Arab Carbonates: a case from the Persian Gulf. J Pet Sci Eng 122:187-207

Dunham RJ (1962) Classification of carbonate rocks according to depositional texture. Am Assoc Pet Geol Bull 1:108-121

Embry AF, Klovan JE (1971) A Late Devonian reef tract on northeastern Banks Island, Northwest territories. Bull Can Pet Geol 19:730-781

Enayati-Bidgoli AH, Rahimpour-Bonab H, Mehrabi H (2014) Flow unit characterization in the Permian-Triassic carbonate reservoir succession at South Pars Gasfield, Offshore Iran. J Pet Geol 37(3):205-230

Esrafili-Dizaji B, Rahimpour-Bonab H (2013) A review of PermoTriassic reservoir rocks in the Zagros area, SW Iran: influence of the Qatar-Fars arch. J Pet Geol 36:257-279

Flügel E (2004) Microfacies of carbonate rocks: analysis, interpretation and application. Springer, Berlin

Hamada GM, Almajed AA, Okasha TM, Algathe AA (2013) Uncertainty analysis ofArchie's parameters determination techniques in carbonate reservoirs. J Pet Explor Prod Technol 3:1-10

Handford CR, Cantrell DL, Keith TH (2002) Regional facies relationships and sequence stratigraphy of super-giant reservoir (Arab-D Member), Saudi Arabia. In: Proceedings of the 22 annual Gulf coast section SEPM foundation, Bob F. Perkins research conference, pp 539-563

Hearn CL, Ebanks WJ Jr, Tye RS, Ranganathan V (1984) Geological factors influencing reservoir performance of the Hartzog Draw field. J Pet Technol 36:1335-1344

Hollis C (2011) Diagenetic controls on reservoir properties of carbonate successions within the Albian-Turonian of the Arabian Plate. J Pet Geol 17(3):223-241

Hollis C, Lawrence DA, De Periere MD, Al-Darmaki F (2017) Controls on porosity preservation within a Jurassic oolitic reservoir complex, UAE. Mar Pet Geol 88:888-906

Hosseini M, Tavakoli V, Nazemi M (2018) The effect of heterogeneity on NMR derived capillary pressure curves, case study of Dariyan tight carbonate reservoir in the central Persian Gulf. J Pet Sci Eng 171:1113-1122

Jodry RL (1992) Pore geometry of carbonate rocks and capillary pressure curves (basic geologic concepts), carbonate reservoir characterization: a geologic engineering analysis: part 1, vol 30. Elsevier Publication, Amsterdam, pp 331-377

Jones GD, Xiao Y (2005) Dolomitization, anhydrite cementation, and porosity evolution in a reflux system: insights from reactive transport models. Am Assoc Pet Geol Bull 89(5):577-601

Kordi M, Morad S, Turner B, Salem AMK (2016) Sequence stratigraphic controls on formation of dolomite: insights from the Carboniferous Um Bogma Formation, Sinai-Egypt. J Pet Sci Eng 149:531-539

Kozeny J (1927) Uber kapillareLeitung des WassersimBoden (Aufstieg, Versickerung und Anwendung auf die Bewfisserung). Sitzungsber. R Acad Sci Vienna 136:271-309

Lindsay RF, Cantrell DL, Hughes GW, Keith TH, Mueller HW, Russell SD (2006) Ghawar Arab-D reservoir: widespread porosity in shoaling-upward sarbonatesycles, Saudi Arabia. Am Assoc Pet Geol Bull 88:475-512 
Lucia FJ (1995) Rock-fabric/petrophysical classification of carbonate pore space for reservoir characterization. Am Assoc Pet Geol Bull 79(9):1275-1300

Lucia FJ (2007) Carbonate reservoir characterization: an integrated approach. Springer, Berlin

Marchionda E, Deschamps R, Cobianchi M, Nader FH, Giuliu AD, Morad DJ, Al-Darmaki F, Ceriani A (2018) Field-scale depositional evolution of the Upper Jurassic Arab Formation(onshore Abu Dhabi, UAE). Mar Pet Geol 89:350-369

Massonnat G, Pernarcic E (2002) Assessment and modeling of high permeability areas in carbonate reservoir. Society of Petroleum Engineers 77591

Mazzullo SJ (1994) Diagenesis in a sequence stratigraphic setting: porosity evolution in periplatform carbonate reservoirs, Permian Basin, Texas and New Mexico. Pet Sci Eng 11:311-322

Moore CH (2001) Carbonate reservoirs porosity revolution and diagenesis in a sequence stratigraphic framework. Elsevier, Amsterdam

Morad S, Al-Aasm IS, Nader FH, Ceriani A, Gasparrini M, Mansurbeg $\mathrm{H}$ (2012) Impact of diagenesis on the spatial and temporal distribution of reservoir quality in the Jurassic Arab D and C members, offshore Abu Dhabi oilfild, United Arab Emirates. GeoArabia 17(3): 17-56

Nabawy BS (2015) Impacts of the pore- and petro-fabrics on porosity exponent and lithologyfactor of Archie's equation for carbonate rocks. J Afr Earth Sci 108:101-114

Nader FH, Boever ED, Gasparrini M, Liberati M, Dumont C, Ceriani A, Morad S, Lerat O, Doligez B (2013) Quantification of diagenesis important on the reservoir properties of the Jurassic Arab D and C members (Offshore, UAE). Geofluids 13:204-220

Nazemi M, Tavakoli V, Rahimpour-Bonab H, Hosseini M, SharifiYazdi M (2018) The effect of carbonate reservoir heterogeneity on Archie's exponents (a and m), an example from Kangan and Dalan gas formations in the Central Persian Gulf. J Nat Gas Sci Eng 59:297-308

Nazemi M, Tavakoli V, Sharifi-Yazdi M, Rahimpour-Bonab H, Hosseini M (2019) The impact of micro-to macro-scale geological attributes on Archie's exponents, an example from Permian-Triassic carbonate reservoirs of the central Persian Gulf. Mar Pet Geol 102:775-785

Perez HH, Datta-Gupta A, Mishra S (2005) The role of electrofacies, lithofacies, and hydraulic flow units in permeability prediction from well logs: a comparative analysis using classification trees. Society of Petroleum Engineers 84301

Perotti CR, Carruba S, Rinaldi M, Bertozzi G, Feltre L, Rahimi M (2011) The Qatar-South Fars Arch development (Arabian platform, Persian Gulf): insights from seismic interpretation and analoguemodelling. In: Schattner U (ed) New frontiers in tectonic research-at the midst of plate convergence. In Tech, pp. 325-352

Porras JC, Campos O (2001) Rock typing: a key approach for petrophysical characterization and definition of flow units, Santa Barbara field eastern Venezuela basin. Evolution of major carbonate producing biota. American Association of Petroleum Geologists,Annual Convention and Exhibition, 11-14 April

Rahimpour-Bonab H (2007) A procedure for appraisal of a hydrocarbon reservoir continuity and quantification of its heterogeneity. $\mathrm{J}$ Petrol Sci Eng 58:1-12
Rahimpour-Bonab H, Mehrabi H, Navidtalab A, Izadi-Mazidi E (2012) Flow unit distribution and reservoir modelling in cretaceous carbonates of the Sarvak Formation, Abteymour Oilfield, Dezful Embayment, SW Iran. J Pet Geol 35(3):213-236

Serag ES, Dernaika MR, AlHasani I, Skjaeveland (2010) Whole core versus plugs: integrating log and core data to decrease uncertainty in petrophysical interpretation and STOIP calculations, Societyof Petroleum Engineers 137679. The Abu Dhabi Intl Petroleum Exhibition and Conference, AbuDhabi, 1-4

Sfidari E, Kadkhodaie-Ilkhchi A, Rahimpour-Bonab H, Soltani B (2014) A hybrid approach for lithofacies characterization in the framework of sequence stratigraphy: a case study from the South Pars gas field, the Persian Gulf basin. J Petrol Sci Eng 121:87-102

Sfidari E, Amini A, Kadkhodaie-Ilkhchi A, Chehrazi A, Zamanzadeh SM (2018) Depositional facies, diagenetic overprints and sequence stratigraphy of the upper Surmeh reservoir (Arab Formation) of offshore Iran. J Afr Earth Sci 149:55-71

Sharifi-Yazdi M, Rahimpour-Bonab H, Tavakoli V, Nazemi M, Kamali MR (2019) Linking diagenetic history to depositional attributes in a high-frequency sequence stratigraphic framework: a case from upper Jurassic Arab formation in the central Persian Gulf. J Afr Earth Sci 153:91-110

Sharland PR, Archer R, Casey DM, Davies RB, Hall SH, Heyward AP, Horbury AD, Simmons MD (2001) Arabian Plate sequence stratigraphy, Geo-Arabia. Spec Publ 2:1-371

Sibley DF, Gregg JM (1987) Classification of dolomite rock texture. J Sedim Pet 57(6):967-975

Soto RB, Torres F, Arango S, Cobaleda G (2001) Improved reservoir permeability models from flow units and soft computing techniques: A case study, Suria and Reforma- Libertad fields, Columbia, Society ofPetroleum Engineers Latin American and Caribean Petroleum Engineering Conference, Buenos Aires, 2528 March 2001, Society of Petroleum Engineers 69625

Swart PK, Cantrell DL, Westphal H, Handford CR, Kendall ChG (2005) Origin of dolomite in the Arab-D reservoir from the Ghawar Field, Saudi Arabia: evidence from petrographic and geochemical constraints. Sed Geol 75(3):476-491

Tavakoli V, Rahimpour-Bonab H, Esrafili-Dizaji B (2011) Diagenetic controlled reservoir quality of South Pars gas field, an integrated approach. Compt Rend Geosci 343:55-71

Wardlaw NC (1996) Factors affecting oil recovery from carbonate reservoirs and prediction of recovery, carbonate reservoir characterization: a geologic engineering analysis part II, vol 44. Elsevier, Amsterdam, pp 867-903

Ziegler M (2001) Late Permian to Holocene paleofacies evolution of the Arabian Plate and its hydrocarbon occurrences. GeoArabia 6:445-504

Publisher's Note Springer Nature remains neutral with regard to jurisdictional claims in published maps and institutional affiliations. 